\title{
Arabs Want Redistribution, So Why Don't They Vote Left? Theory and Evidence from Egypt Faculty Research Working Paper Series
}

\section{Tarek Masoud}

Harvard Kennedy School

\section{April 2013 \\ RWP13-007}

Visit the HKS Faculty Research Working Paper series at:

http://web.hks.harvard.edu/publications

The views expressed in the HKS Faculty Research Working Paper Series are those of the author(s) and do not necessarily reflect those of the John F. Kennedy School of Government or of Harvard University. Faculty Research Working Papers have not undergone formal review and approval. Such papers are included in this series to elicit feedback and to encourage debate on important public policy challenges. Copyright belongs to the author(s). Papers may be downloaded for personal use only. 


\title{
Arabs want redistribution, so why don't they vote left? Theory and evidence from Egypt
}

\author{
Tarek Masoud*
}

\begin{abstract}
Though Egyptian voters clearly evince a desire for Islamic law (however defined), public opinion research shows that they also want robust welfare states and significant redistribution. Though the application of Islamic law is the special province of Islamist parties, it is left-leaning, labor-based parties who are the primary champions of the economic policies that Egyptians seem to desire. Why, then, do Egyptian voters select the former over the latter? This article argues that the answer lies not in the political unsophistication of voters, the subordination of economic interests to spiritual ones, or the bureaucratic and organizational shortcomings of leftist parties, but in the ways in which the social landscape shapes the opportunities of parties in newly democratized systems to reach potential voters. Dense networks of religious solidary organizations, in which Islamist activists are often embedded, and which encompass large numbers of voters, provide Islamist parties with opportunities for linkage that are unavailable to leftists, who are embedded in much more limited networks of labor activism. As a result, despite the fact that Islamist attitudes toward redistribution and the state's role in providing welfare are more ambiguous than those of leftists, Islamist candidates have far greater opportunities to convince voters that they in fact share their economic views. The theory is tested with a combination of aggregate and individual evidence from Egypt after the Arab Spring.
\end{abstract}

\section{The Islamist Arrival}

The two years since the overthrow of Egypt's long-reigning dictator, Husni Mubarak, have not been kind to the forces of liberalism and secularism in that country. Though the mass protests that resulted in Mubarak's departure seemed at first

*Thanks to Ali Asani, Soha Bayoumi, David Dapice, Marshall Ganz, Sona Golder, Jill Goldenpine, Amaney Jamal, Amani Kandil, Victor Menaldo, Burt Monroe, Todd Mostak, Ahmed Ragab, Sara Roy, Burcin Tamer, Joseph Wright, Vineeta Yadav, and participants in the workshop on Civil Society in the Arab Region, Radcliffe Institute for Advanced Study, Harvard University, February 7-8, 2013; the Al-Waleed Ibn Talal Islamic Studies Faculty Seminar, February 20, 2013; and the Pennsylvania State University Conference on Political Change and the Arab Spring, February 23, 2013. All errors are mine. Comments welcome: Tarek_Masoud@Harvard.edu . 
to have been organized and led by liberal young people, the post-revolutionary period has seen an almost unbroken string of Islamist triumphs. ${ }^{1}$ First, in January 2012, two Islamist political parties, the Freedom and Justice Party (Hizb al-Hurriyah wa al-'Adālah) - the political arm of the 85-year old Society of Muslim Brothers (Jamä'at al-Ikhwān al-Muslimūn) —and an even more conservative newcomer called the Party of Light (Hizb al-Nūr), won more than two-thirds of the seats in parliament (before the body was dissolved by the country's highest court). ${ }^{2}$ In June 2012, the Muslim Brotherhood's Mohamed Morsi won the country's presidency, and six months later, the Brotherhood and its allies enacted a constitution that secular opposition leader Mohamed ElBaradei decried as violating "freedom of religion, freedom of expression, [and] independence of the judiciary." 3 The eighteen days from January 25, 2011 to Mubarak's resignation on February 11, in which the faces Egypt presented to the world were not those of bearded Islamists, but of liberals and socialists and Western-educated technocrats, seem distant indeed.

For many, the political ascent of the partisans of political Islam was unsurprising. Scholars, journalists, and even Mubarak himself had long predicted that democratic openings in Egypt would bring Islamists to power. In 2006, the scholar Fawaz Gerges declared that "if free and open elections were held today, the Broth-

\footnotetext{
${ }^{1}$ In this essay, I define Islamist parties as those that arise out of Islamic pietist movements, such as the Muslim Brotherhood (Jamä'at al-Ikhwān al-Muslimūn) or the Salafi Call Society (Jamátat al$D a^{\prime}$ wa al-Salafiyya). These parties invariably call for the application of some version of shar'tah, but I refrain from using a stated desire for shar'tah as a definitional criterion because Egyptian parties generally recognized as non-Islamist often pay lip-service to sharîtah as well. For example, Islamic themes once figured prominently in the platform of Egypt's ruling National Democratic Party, which, according to Egyptian columnist Fahmī Huwaydī, called not only for the primacy of the shar' ${ }^{\prime} a h$, but for the strengthening of religious education and the use of state-owned media for the reinforcement of religious principles and values. See: Fahmī Huwaydī, "Misr ... Al-Marjā'iyya al-Dinniyya Bayn al-Hazr wa al-Tawzîf (Egypt: The Religious Frame of Reference Between Prohibition and Exploitation)," Al-Sharq al-Awsat, Issue 10347, 28 March, 2007. Similarly, the platform of Egypt's Wafd party-long referred to as "secular," "liberal," or both-declares that, "Islam is the official religion of the state and therefore the Islamic shari'a must be the principal source of legislation." (See: Birnāmij Hizb al-Wafd: Al-Shu'ūn al-Dīniyya (Wafd Party Platform: Religious Matters). Available at http://www.alwafdparty.org/details.aspx?t=prog\&id=136.) An alternative, and useful, definition of Islamism is provided by Hegghammer $(2013,1)$, who calls it "activism justified with primary reference to Islam." Although what constitutes "primary reference" is of course subjective.

${ }^{2}$ Arabic terms and proper names have been transliterated according to the system established by the Middle East Studies Association (http:/ / web.gc.cuny.edu/ijmes/docs/TransChart.pdf), except in cases where there is an established English rendering. (Thus, I write Gamal Abdel Nasser, Mohamed Morsi, and Mohamed ElBaradei instead of Jamāl 'Abd al-Nāṣir, Muhammad Mursī, and Muhammad al-Barād'̄i.)

3 "ElBaradei: Egypt's Draft Constitution Will Institutionalize Instability," PBS NewsHour, December 24, 2012. Available at: http://www.pbs.org/newshour/bb/world/july-dec12/egypt2_1224.html; For a thorough analysis of the new Egyptian constitution, see Nathan J. Brown, "Egypt's Constitution Conundrum: The Good, Bad, and the Unruly in Cairo," Foreign Affairs, December 9, 2012 (available at http://www.foreignaffairs.com/articles/138495/nathanj-brown/egypts-constitution-conundrum); and Nathan Brown and Clark Lombardi, "Islam in Egypt's New Constitution," Foreign Policy, December 13, 2012 (available at: http://mideast.foreignpolicy.com/posts/2012/12/13/islam_in_egypts_new_constitution).
} 
erhood would win a comfortable majority." ${ }^{4}$ That same year, the New York Times informed us that the Brothers "would probably sweep any wide-open elections." Likewise, in 2007 an Israeli official testified that "if free elections were held in Egypt today, the Muslim Brotherhood would win by a landslide." ${ }^{6}$ Hishām Mubārak, the late Egyptian human rights activist (and no relation to the former dictator), confided to Miller $(1996,65)$ that "if the Brotherhood ever ran in a free election, it would win overwhelmingly." More restrained was the analysis of the Jerusalem Report more than twenty years ago, which ascribed to "many observers" the belief that, if the Brotherhood "ran free elections and was given free access to the media, its supporters would take no more than 10 years to become the parliamentary majority." ${ }^{\prime 7}$

The simplest explanation for the dominance of Islamists in post-revolutionary Egypt is that Islamists win because Muslims want what they are selling. According to the historian Bernard Lewis, Muslims are taught that enforcing shari ${ }^{\prime} a h$ law (despite the lack of agreement on precisely what this requires) and Islamizing the polity are religious imperatives. "In Islam [...]," Lewis writes, "there is from the beginning an interpenetration, almost an identification, of cult and power, or religion and the state: Mohammed was not only a prophet, but a ruler" (Lewis 1996, 61). In contrast, he tells us, Christians "have distinguished between throne and altar, church and state." This narrative is echoed by the political scientist James Q. Wilson, who tells us: "Jesus asked Christians to distinguish between what belonged to God and what belonged to Caesar. Islam made no such distinction; to it, Allah prescribed the rules for all of life, encompassing what we now call the religious and secular spheres." ${ }^{8}$ Conditioned by their faith to demand theocracy, this line of argument goes, Muslims cast their suffrages for parties that promise to impose God's will on Earth.

Such accounts have long been dismissed as essentializing (Said, 1978; al Azm, 1997), but they remain influential, in part because we continue to amass empirical evidence that seems to support them. In the periodic surveys of Egyptian public opinion that have been conducted over the last several years, one of the few empirical regularities that emerges is a popular desire for the application of sharitah (however construed), which is a principal plank in many an Islamist party's platform. For example, in 2000, the World Values Survey found that almost $80 \%$ of the 3,000 Egyptians they surveyed agreed with the statement: "The government should implement only the laws of the shari' $a{ }^{\prime} .{ }^{\prime \prime}$ More recently, in a November

\footnotetext{
${ }^{4}$ Fawaz A. Gerges, "Making Sense of the Cartoon Controversy: From Protests to Recent Elections, Islamists Hold Sway," ABC News, February 8, 2006. Available at http:/ / abcnews.go.com/International/story?id=1595281\&page=1.

5 James Glanz, "A Little Democracy or a Genie Unbottled," New York Times, January 29, 2006

${ }^{6}$ Uri Dromi, "Reverberations in Egypt: Gaza Fallout," International Herald Tribune, June 22, 2007. Available at http://www.iht.com/articles/2007/06/22/opinion/eddromi.php.

7 Jeffrey Phillips, "A Holy War on the Nile," Jerusalem Report, June 18, 1992

8 James Q. Wilson, "The Reform Islam Needs," Wall Street Journal, November 13, 2002

${ }^{9}$ World Values Survey, third wave, Egypt, $2000 . \quad$ Available at: http:/ / www.worldvaluessurvey.org/
} 
2011 survey of 1,675 Egyptians, this author found that only 13\% of respondents disagreed with the proposition that the "government should establish a council of religious scholars to ensure that the laws comply with the shari $\bar{l}^{\prime} a h,{ }^{\prime}$ which might help explain why the fourth article of Egypt's recently enacted constitution now accords precisely this role to the country's largest seat of Islamic learning, al-Azhar.

But, although public opinion polls evince broad support for the idea of implementing some version of shari ${ }^{\prime} a h$, they also reveal that shari $\bar{i}^{\prime} a h$ is not the only thing Egyptians care about. For example, Egyptians routinely espouse identifiably "leftist" policies and programs in numbers almost as great as those demanding Islamic law. When Egyptians were asked by the 2005 World Values Survey where they would place themselves on a continuum from "left" (al-yasār) to "right" (alyamin), approximately $40 \%$ placed themselves on the left (see figure 1). Similarly, in a survey of 1,675 Egyptians conducted in late 2011, respondents revealed strong preferences for the kinds of welfare-statist, redistributive policies that are the hallmarks of leftist party platforms. ${ }^{10}$ For example, respondents were asked to place themselves along a continuum from 1 to 10, where 1 represented the belief that the welfare of individuals is the responsibility of the government, and 10 represented the belief that individuals should be responsible for their own welfare. The vast majority endorsed the statist view (see figure 2). Similarly, when citizens were asked whether the government should focus on redistribution and equality, or ignore equality and focus solely on economic growth, the vast majority displayed a strong preference for redistribution (see figure 3). ${ }^{11}$

However, despite this thirst for statist, redistributive policies that seems every bit as robust as the supposed desire for sharíah, parties of the left have performed poorly in Egyptian elections. During the 2011-12 parliamentary election, the newly-formed Egyptian Social Democratic Party (al-Hizb al-Dimuqrāți al-Ijtima $\left.\bar{a}^{\prime} \hat{\imath}\right)$ a member of the Socialist International-captured only sixteen seats. ${ }^{12}$ Its electoral ally, the National Progressive Unionist Rally (Hizb al-Tajammu' al-Watani alTaqaddumi al-Wahdawī) long the standard-bearer of the left in Egypt (its website declares itself "the home of the Egyptian left"), garnered only three. ${ }^{13}$ Nor is this a

\footnotetext{
${ }^{10}$ Conducted by the author in collaboration with Ellen Lust of Yale University

${ }^{11}$ In each question, respondents were presented with two contrasting policy options, each at either end of a ten point scale, and asked where along that scale they would situate themselves. For the first question, the two poles were "government should be responsible for the welfare of every citizen" and "citizens should be responsible for their own welfare." In the second question, the two poles were "the government should raise taxes on the rich in order to give to the poor" and "the government should focus on economic growth and not social equality." Survey questionnaire is available at http:/ / www.tarekmasoud.com/data /

12 The Socialist International describes itself as "the worldwide organisation of social democratic, socialist, and labour parties" (see: http://www.socialistinternational.org/about.cfm). Though membership in the SI is usually a marker of a party's leftist credentials, it is only imperfectly so. After all, Egypt's former ruling National Democratic Party-which spearheaded privatization initiatives in Egypt under the guidance of president Mubarak's son Gamal-was a member of the SI from 1989 until its explusion shortly after the beginning of the January 25, 2011 protests. See Joshua Keating, "Socialist International finally kicks out Mubarak," ForeignPolicy.com, February 3, 2011.

13 The NPUR's website, and its moniker "bayt al-yasār al-mișrī (home of the Egyptian left)" can be viewed here: http://altagamoa.com. The NPUR was founded in 1977 by Khālid Muhyī al-
} 
Fig. 1: A significant proportion of Egyptians place themselves on the "left" politically. (Source: World Values Survey, Egypt, 2005)

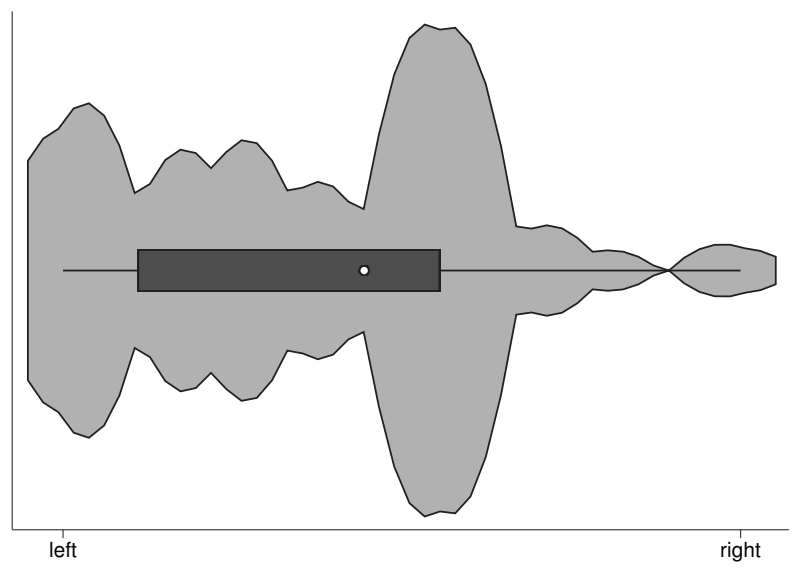

Fig. 2: Most Egyptians believe that the government, as opposed to the individual, is responsible for citizens' well-being (November 2011).

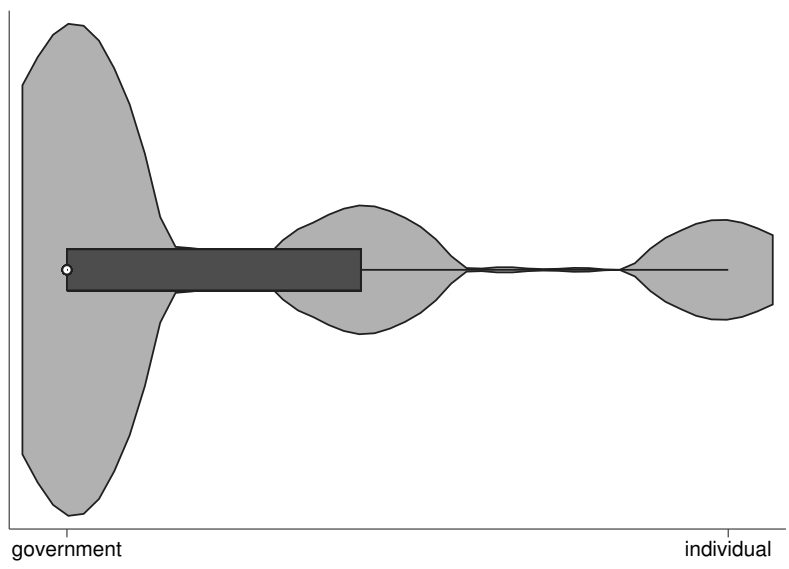


Fig. 3: Most Egyptians want the government to focus on redistributing wealth rather than simply maximizing economic growth (November 2011).

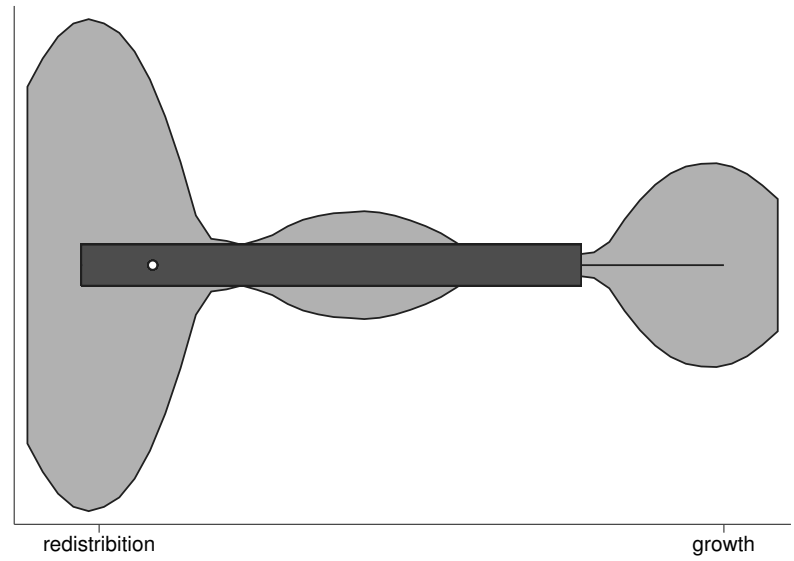

new phenomenon. The NPUR never earned more than 6 of 444 seats in parliament during the Mubarak era, whereas the Muslim Brotherhood at its peak held a fifth of the seats in the country's rubber stamp legislature.

The ability of Islamists to outperform parties that so clearly represent the economic concerns of vast numbers of Egyptians brings to mind Lila Abu Lughod's $(1995,54)$ prescient question, asked during an earlier season of Islamist activism, of "why a political discourse in which morality displaces class as the central social problem is so appealing." After all, it is frequently reported that $40 \%$ of Egyptians subsist on less than two dollars per day (although the latest available statistics from the World Bank put the figure at $15.4 \%$ ). ${ }^{14}$ The country's per capita income of $\$ 5,349$ places it in the lower half of nations, and ranked by its score on the United Nations Development Programme's human development index (which aggregates health, education, and national income indicators), Egypt places 112th, behind

Dīn, a member of Nasser's Free Officer's group who eventually split from the military junta and spent some time in exile. Sadat had labeled him "the Red Major" due to his Communist leanings. See Khaled Dawoud, "The Red Major," Al-Ahram Weekly, No. 595, 18-24 July 2002. Available at: http:/ / weekly.ahram.org.eg/2002/595/sc81.htm

14 The figure of $40 \%$ living on less than $\$ 2$ per day is misleading. First, it is more than 7 years old. But more importantly, the original source, the 2006 World Development Indicators, tells us that $43.9 \%$ of Egyptians subsist on less than $\$ 2.15$ per day in 1993 international prices, not current prices. Given inflation, \$2 in 1993 prices is approximately \$3 in current (2012) prices. However, this important distinction is neglected in most scholarly testimony that cites the $40 \%$ figure-see for example Tadros (2005), El-Khawas (2012), Bush (2011), as well as Amitai Etzioni, "It's the Egyptian Economy, Stupid," The National Interest, January 24, 2013. The figure is similarly invoked by journalists. See, for example, John Ydstie, "Empty pockets stoked discontent in Egypt, Tunisia," National Public Radio, February 1, 2011; Jeffrey Fleishman, "Under Egypt's political unrest seethes the rising anger of the poor," Los Angeles Times, February 2, 2013; Tony Karon, "From bad to worse: Economic woes may compound Egypt's pain," Time, January 29, 2013; Yolanda Kell, "The complicated legacy of Egypt's Hosni Mubarak," BBC News, January 25, 2013. The 2006 World Development Indicators with the relevant figure are available here: http://data.worldbank.org/sites/default/files/wdi06.pdf 
Cape Verde and Guatemala and just ahead of Nicaragua. ${ }^{15}$ Presumably, these disadvantaged masses should constitute a ready constituency for a politics of radical redistribution. The fact that they instead vote for Islamists might cause one to wonder whether Egyptians are laboring under a kind of false-consciousness, prioritizing spiritual matters above the economic ones that determine, in a very real sense, how much they eat and how long they live. To expropriate the title of a well-known book, should we be asking "What's the Matter with Cairo?"16

In this article, I argue that Islamist successes and leftist disappointments are neither a function of the political unsophistication of voters nor of the subordination of economic interests to spiritual ones, but are functions of differences in the opportunities for linkage to voters faced by Islamist and leftist parties at moments of political opening. Legacies of authoritarian governance, as well as patterns of economic development, generate a social landscape rich in religious networks, and poor in networks of social action based on class or occupation. As a result, Islamists possess multiple opportunities to communicate with voters and convince them of their fealty to their interests, whereas leftists-who may actually be truer to those interests-simply lack equivalent opportunities. Thus, though the majority of poor Egyptian voters prefer significant redistribution and a large welfare state, they are unable to connect these preferences with the parties that most espouse them, voting instead for Islamist politicians who, by virtue of their embeddedness in dense networks of religious organizations, are able to speak to voters in ways that leftists are not.

The article proceeds as follows: First, I explore two potential explanations for the success of Islamists over leftists - the first is that voters prioritize issues of religion above economic ones, and the second is that Islamist parties are actually more redistributive and welfare-statist than self-described leftist parties. The evidence suggests neither is true: voters do not appear to give religious issues priority over economic ones, and Islamists do not appear to be more leftist than either Egypt's leftist parties or its median voter. However, despite this, I find that voters do perceive Islamist parties to be more welfare-statist and redistributive than their leftist rivals. I then outline an argument to account for this perception, and test it with aggregate and individual-level evidence from Egypt. I conclude by examining the implications of the argument for the emergence of political parties based on the economic interests of the poor in developing countries, as well as the prospects of enhanced political competition and pluralism in Egypt as its democratic experiment (hopefully) moves forward.

\footnotetext{
${ }^{15}$ Human Development Report 2009, United Nations Development Programme. See http://hdrstats.undp.org/en/countries/country_fact_sheets/cty_fs_EGY.html

16 Thomas Frank, What's the Matter with Kansas? How Conservatives Won the Heart of America, Henry Holt and Co., 2004.
} 


\section{Islamist parties and redistribution}

One does not have to go all the way with the likes of Lewis to believe that Islamism wins because voters simply want Islam. The so-called secularization thesis-which holds that the salience of religion is inversely related to prosperity - would suggest that Egyptians vote for the Muslim Brotherhood and its ilk not because of Islam, but because of underdevelopment (Norris and Inglehart, 2011). Weber (1946) argued that development-the term he used was "modernity" — changes the way individuals think: "The fate of our times," he wrote, "is characterized by rationalization and intellectualization and, above all, by the disenchantment of the world." Similarly, Lipset and Rokkan $(1967,107)$, argued that citizens in industrialized societies "choose sides in terms of their economic interests, their shares in the increased wealth generated through the spread of the new technologies and the widening markets," rather than on the basis of faith, identity, or values. By these lights, we might expect Egypt's endemic poverty, high rate of illiteracy, and large agrarian sector to mean that its citizens have not yet undergone these salutary rationalization processes, and thus remain vulnerable to religion's siren song, prioritizing matters of faith above their "real" economic interests.

However, this narrative is at odds with much recent scholarship on Egyptian politics. Blaydes (2006), for example, has documented the ways in which poor Egyptian voters during Mubarak-era elections sold their suffrages to the highest bidder, displaying not a lack of rationality, but a surfeit of it (see also Lust-Okar 2006). Several scholars and journalists have noted the fact that the Muslim Brotherhood primarily recruits well-educated Egyptians of the middle classes-precisely the kinds of people that Weber thought were most likely to have outgrown the kind of enchanted thinking he associated with deep religious belief (Ibrahim 1980, Al-Sayyid 1993, Fahmy 1998, Clark 2004, Masoud 2008). Moreover, most Egyptian public opinion data does not support the proposition that voters prioritize matters of faith above economic issues. For example, in a survey of 1,200 Egyptians conducted by the Ahram Center for Political and Strategic Studies in May $2012,68.5 \%$ of respondents said that the economy was the most urgent issue facing Egypt. ${ }^{17}$ We see the same patterns in another al-Ahram poll, conducted twelve years earlier: the vast majority of 1,600 respondents in a 2000 survey also identified economic issues as Egypt's primary challenges, with more than a third citing the "labor market," and another quarter citing the "economic situation." In fact, only around $15 \%$ of those polled pointed to "social problems" (mashäkil ijtimä'iyya)—an admittedly vague category, but one that comes closest to encompassing the issues of moral decay with which Islamists are supposed to be concerned. ${ }^{18}$

\footnotetext{
17 Șubḥī ‘Isaila, "al-Iqtiṣād wa al-amn... al-matlabān al-aham lil-mișriyīn (The economy and security... the two most important demands of Egyptians)," in "Kayf Yufakir al-Mișriyūn? (How do Egyptians think?)," al-Ahrām (insert), June 14, 2012. Available at: http://dedi.org.eg/wpcontent/uploads/DED-Ahram-insert-Arabic.pdf

18 Thanks to Subhi 'Isaila of the Ahram Center for providing me with this data. The sample included 747 men $(46.69 \%)$ and 853 women $(53.31 \%)$. Sample is stratified with respect to governorate. Cairo and Alexandria account for $24.38 \%$ of sample; Nile Delta governorates for 44.38 ; and Upper
} 
If Egyptians are not prioritizing faith above economic interest, could it be that Islamist parties win votes because they equal or surpass leftist parties in their fealty to redistribution and the welfare state? The evidence on this score is mixed. On the one hand, Brotherhood parliamentary candidates frequently deploy populist language-railing against high prices, unemployment, and inequalities of wealth-and the FJP's electoral platform promises to remedy the latter problem by passing "a law specifying a minimum wage and also a maximum wage."19 However, the Brotherhood has also staked out policy positions that put it adds with the sentiments of a majority of Egyptian voters. For example, the New York Times reports that in a March 2012 meeting with a group of American lawmakers (including Republican senator Lindsey Graham of South Carolina), the Muslim Brotherhood's deputy general guide Khayrat al-Shātir "assured them of the group's commitments to free-market capitalism." 20 Thus, after the Brotherhood won a plurality of seats in last year's parliamentary elections, the head of a major Egyptian bank reported that the Brotherhood's rise did not trouble him, because the FJP was "capitalist in its thinking." 21

In fact, if we widen our temporal aperture, we see that the Brotherhood has long championed "capitalism and private property" (Abu Lughod 1995, 54) and has traditionally tended to resist state interventions in the economy. For example, according to Abed-Kotob $(1995,327)$, in the 1970s, the Brotherhood's leaders supported Sadat's policies of opening Egypt to trade (popularly known as infitāh) and paring down the massive public sector built up during the rule of his predecessor, Gamal Abdel Nasser (1954-1970). According to Lesch (1995, 231), the Brotherhood's electoral programs featured economic demands that were "congruent with the government's own approach, including the call to decrease the size of the public sector and reinforce the private sector as the backbone of the economy." Given these contradictory signals, the most that can be said of the Brotherhood's commitment to the core economic beliefs of the average Egyptian voter is that it is unclear.

The same is true of the Salafi Party of Light (or Nūr Party). As with their Muslim Brotherhood counterparts, Salafi candidates beat the populist drum on the campaign trail, speaking of "just distribution of wealth" and "expanding the umbrella of social insurance." 22 However, the party's economic program appears remarkably market-oriented. In July 2011, three months before the parliamentary elections that would give it the second largest share of seats in the legislature, the party convened a conference that laid out a plan for Egypt's economic renaissance.

Egypt for $31.25 \%$.

19 Available at: http://www.hurryh.com/Party_Program.aspx

${ }^{20}$ David D. Kirkpatrick, “The New Islamists: Keeper of Islamic Flame Rises as Egypt's New Decisive Voice," The New York Times, March 12, 2012.

${ }^{21}$ Aḥmad Ya'qūb, "Al-Sibā'î: Șu'ūd al-Islāmiyīn lan yu'athir 'alā al-bunūk (Al-Sibā'î: The rise of Islamists will not affect the banks)," al-Yawm al-Sabi' (Cairo), January 4, 2012.

22 "Al-birnamij al-intikhabi wa al-sira al-thatiyya lil-murashah Sayyid Maghawri al-Jiyushi (Electoral program and biography of the candidate Sayyid Maghawri al-Jiyushi)," Nur Party flyer, October 2011. al-Jiyushi was a candidate in Giza's third district, covering Imbaba, Duqi, and al-'Aguza. 
It called for establishing an "Islamic chamber of commerce" that would "attract owners of capital from among the party's sons;" setting up an Islamic bank; encouraging businessmen to fund small projects and micro-loans; helping "to transmit the voices of Islamic businessmen to decision-making circles;" and preparing "economic legislation to [...] lift the tariffs and tax burdens that grievously harm the Egyptian economy."23

Further evidence that Islamist economic preferences may not be in line with those of most Egyptians can be found in the constitution passed by the Islamistdominated constituent assembly on November 29, 2012. Although it is the religious provisions of Egypt's new charter that have received the most attention, the document also appears to advance a neoliberal vision for the economy, including "linking wages to productivity" (Article 14); preventing the establishment of independent trade unions and limiting official unions to "one per profession" (Article $53)^{24}$; enabling legal restrictions on the right to strike (Article 63); and retrenching the state's longstanding commitment to provide free healthcare for all, instead offering the more modest promise to provide gratis care only "to those who are unable to pay" (Article 62). ${ }^{25}$

Though the Muslim Brotherhood and its religious counterparts may not be the foremost champions of redistribution or of the role of the state in the economy, it may be that voters perceive them to be. In the November 2011 survey cited above, Egyptians were asked not only to identify their own ideal points on issues of redistribution and the role of government in ensuring citizens' welfare, they were also asked to indicate where they think each political party's ideal point lies. Figures $4 \mathrm{a}$ and $4 \mathrm{~b}$ provide the mean self-placement, and the mean perception of where some of the principal parties stand, on each of these two issues. To simplify the presentation, I have included the two Islamist parties - the Brotherhood's Freedom and Justice Party (FJP) and the Salafi Nūr Party—the secular Free Egyptians Party (Hizb al-Mișriȳn al-Ahrār , here abbreviated as FEP), the leftist NPUR, and the Wafd Party (established early in the 20th century and one of the principal opposition parties during the Mubarak era).

As is evident in both figures, Egyptians on average placed themselves to the "left" of all political parties, Islamist or otherwise. But, among the political parties, they identified the FJP and the Nūr party as being the most left-leaning. In other words, Egyptians appear to think that the Islamists favor redistribution over

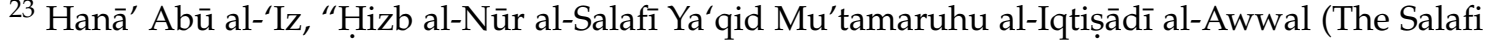
Nūr Party Holds its First Economic Conference)," al-Yawm al-Sābi' (Cairo), July 24, 2011 (available at: http://www1.youm7.com/News.asp?NewsID=460599\&SecID=296\&IssueID=0) and Nādir Bakkār, "Wașiyāt Mu'tamar Hizb al-Nūr al-Iqtiṣādī al-Awwal (Advice of the Nūr Party's First Economic Conference)," July 28, 2011. Available at: http:/ thenokhba.blogspot.com/2011/07/1.html

${ }^{24}$ It can be argued that the establishment of industry-wide unions will actually increase wages (Calmfors and Driffill 1988), although empirical work by Golden (1993) suggests that industry-level unions of the kind envisioned by the Egyptian constitution can work to moderate wage demands if they are small in number and have monopolies over their members.

25 The text of the present Egyptian Constitution, passed on December 23 with $64 \%$ of the vote (33\% voter turnout), is available in Arabic here: http://dostour.eg/, and in English here: http://www.acus.org/egyptsource/unofficial-english-translation-egypts-draft-constitution
} 
Fig. 4: Mean placement of parties and mean self-placement on economic issues.

(a) Redistribution vs. growth

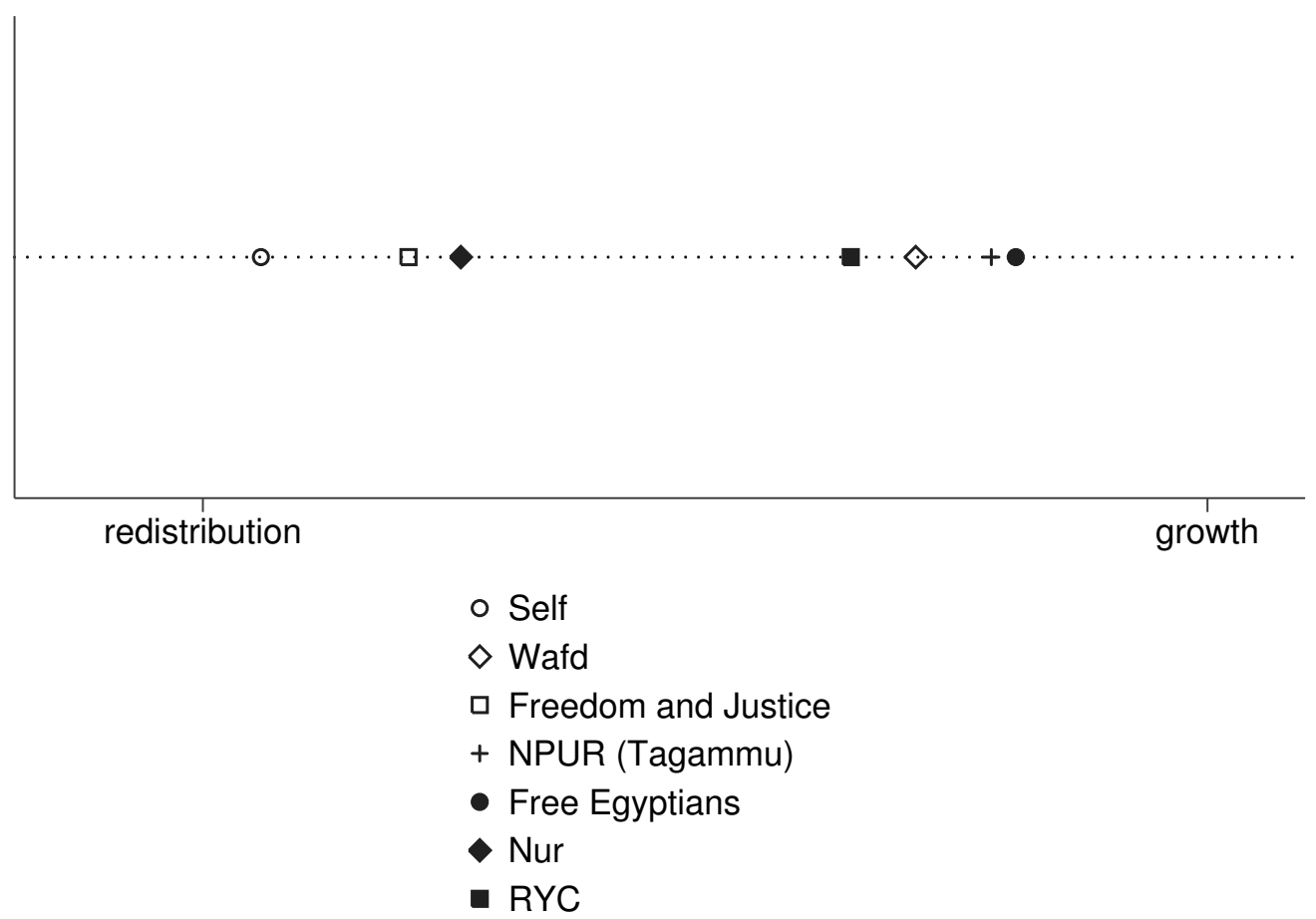

(b) Government vs. individual responsibility

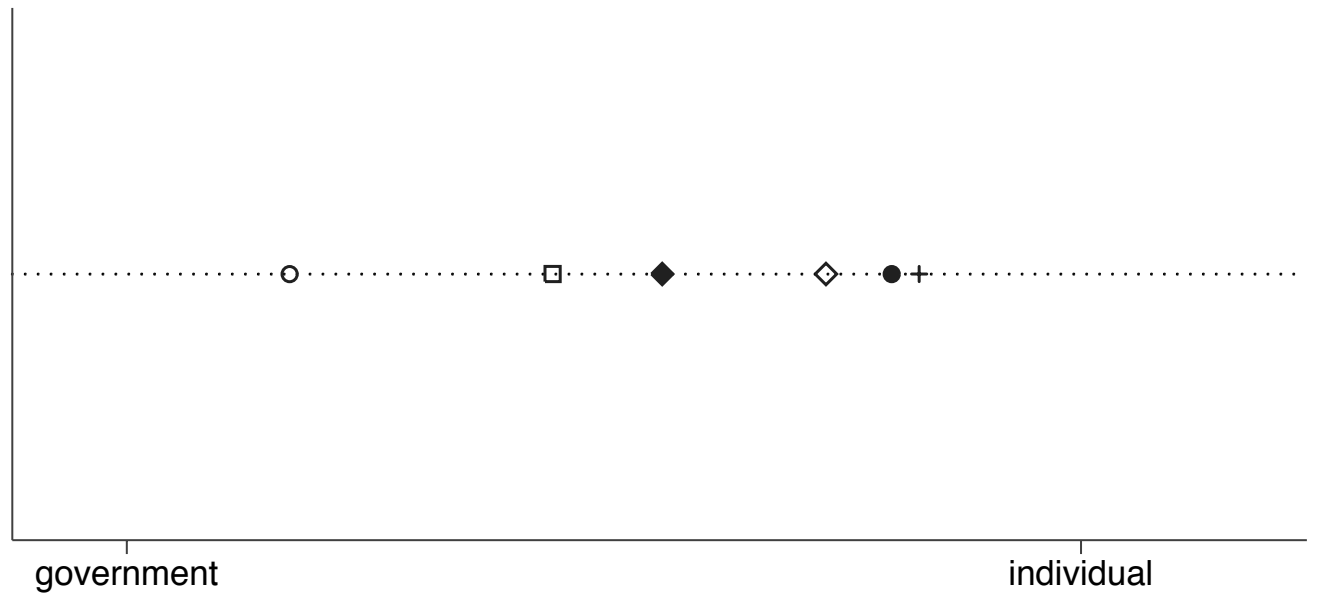


Fig. 5: Egyptians feel that they know more about Islamist parties' economic positions than those of their rivals, especially leftist ones.
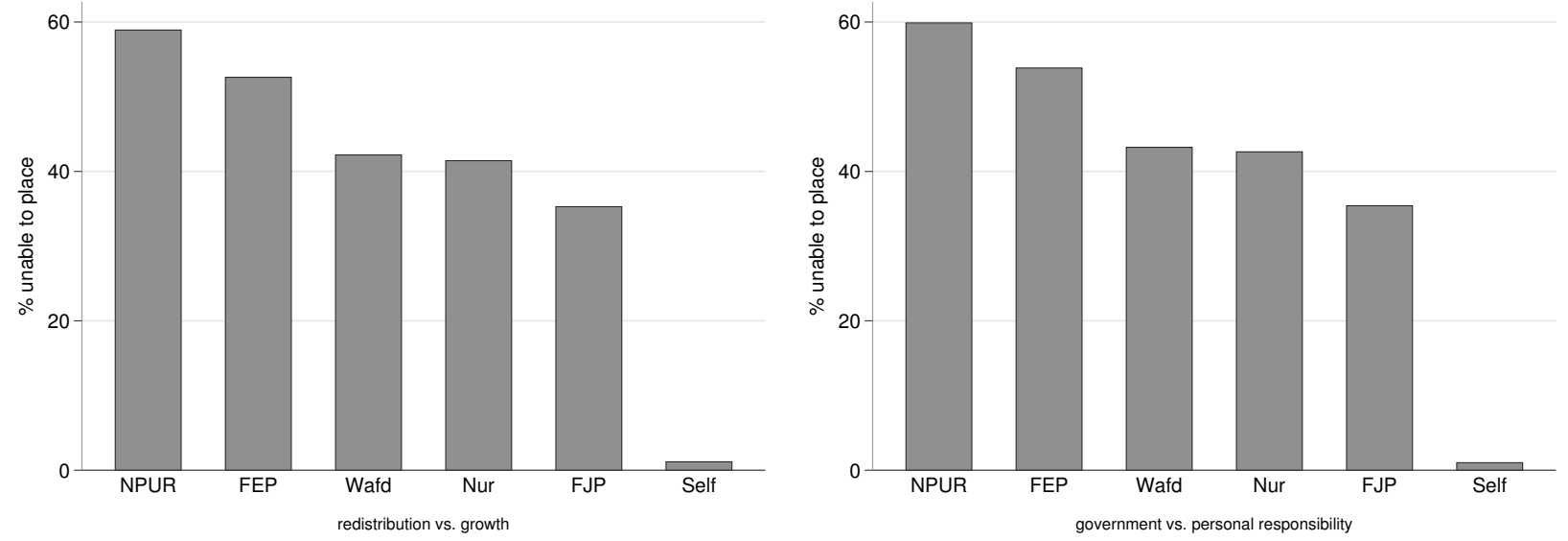

growth, and they think that Islamists believe that the government is responsible for the welfare of individuals. More importantly, respondents appeared to think that Islamists are more redistributive and more welfare-statist than parties like the NPUR, a party that describes itself as "the party of workers and farmers," 26 and whose current program declares that it "puts its thought and its struggle in the service of the millions who suffer under current conditions, especially the working classes."27 What is remarkable here is less that voters may be getting Islamist economic positions wrong, and more that they are certainly getting leftist ones wrong.

The ignorance of voters regarding the substantive policy positions of leftist parties is further illustrated in figure 5, which indicates the percentage of those surveyed who responded "don't know" when asked to place themselves or the various political parties on the questions of redistribution and government responsibility for welfare. Approximately $60 \%$ of respondents declared ignorance of the NPUR's position on the two economic issues, whereas only around $40 \%$ of respondents declared ignorance of the stances of the Nūr Party (which had only been established six months before), and only $36 \%$ said they did not know where the Brotherhood's FJP stood. (For comparison's sake, I have included the percentage of individuals who responded "don't know" when asked to indicate their own policy preferences on the two questions.) Thus, it seems clear that few voters know where leftist parties stand, and when they think they do know where these parties stand, they are invariably wrong.

Would more Egyptians vote for leftist parties if they actually knew what those parties stood for, and how proximate these parties are to voters' own ideal points?

\footnotetext{
${ }^{26}$ Party flyer entitled "Hizb al-Tajammu' al-taqadumi al-wahdawi: Man nahnu? (The National Progressive Unionist Rally: Who are we?)" 2011.

27 "Building a Society of Popular Participation (Binā' Mujtama' al-Mushāraka alSha'biyya)," National Progressive Unionist Rally, October 1, $2012 . \quad$ Available at: http:/ / altagamoa.com/index.php/2012-06-30-00-38-17/2012-06-30-00-36-39/472-2012-10-0115-01-07
} 
This is a difficult question to answer definitively, but it seems self-evident that voter ignorance about leftist parties' economic positions cannot help the left's cause. For example, Pepinsky, Liddle, and Mujani (2012) demonstrated that voter uncertainty about Indonesian parties' economic platforms redounded to the benefit of Islamists, and that this advantage disappeared once voters knew more about parties' economic positions. Given the congruence between voters' economic attitudes and those of leftist parties, it is reasonable to assume that leftist fortunes could not help but be buoyed by increased public recognition of this fact. The question for this article, then, is why the uncertainty regarding the preferred economic policies of leftist parties-and the misplaced certainty regarding the preferred economic policies of Islamists- exists in the first place?

\section{Organizational factors}

At this point in our inquiry, it seems that the answer to both the question of why Islamists outperform their secular and leftist rivals, and why voters seem to know so little about the policy positions of those rivals, lies in attributes of the parties rather than in the preferences of voters. Specifically, if leftist party weakness is not a function of popular antipathy to large welfare states or massive redistribution, then it is because Islamist parties are doing something that leftists are not. Are leftist parties simply worse than Islamists at communicating their policy preferences to voters?

Most observers of Egypt would answer in the affirmative, and argue that the principal difference between the energetic Islamists and the moribund left is one of organization. For example, the scholarly and popular literature is replete with references to the Muslim Brotherhood as the "most organized"28 and "most disciplined" ${ }^{29}$ Egyptian political group, while leftist and secular parties are called "ineffectual," "feckless," "divided," "disorganized," "lazy," and-in one particularly memorable formulation-"cartoon parties." ${ }^{30}$ The Muslim Brotherhood's organizational advantage is usually attributed to its selectivity with respect to the recruitment of new members, its stringent requirements for advancement within the organization, and its employment of a Leninist, clandestine cell system (Rubin

\footnotetext{
${ }^{28}$ See, for example, Anthony Shadid, "Egypt's path after uprising does not have to follow Iran's," New York Times, February 12, 2011; Condoleezza Rice, "The future of a democratic Egypt," Washington Post, February 16, 2011; Kristen Chick, "Egypt vote is on, despite deadly protests. How will the Muslim Brotherhood do?" Christian Science Monitor, November 27, 2011; among many others.

${ }^{29}$ See, for example, "Protest in Egypt: Another Arab regime under threat," The Economist, January 27, 2011; "Egypt's Revolution: Mubarak now has few good options for retaining power," Wall Street Journal, January 29, 2011; Jeffrey T. Kuhner, "Obama's anti-Israel agenda," Washington Times, February 17, 2011; and Hamza Hendawi and Sarah El Deeb, "Raucous start to Egypt's newly elected parliament," Associated Press, January 24, 2012, among many others.

${ }^{30}$ See, for example, Dina Salah Eldin, "As Egypt prepares to vote, only one side seems organized," National Public Radio, December 14, 2012; Marina Ottaway, "The Unfinished Egyptian Transition," The National Interest, January 25, 2013; Amir Taheri, "Will Egypt's Democrats Get Serious?" New York Post, February 27, 2013; Gert Van Langendonck, "Egypt's opposition still hopeful, despite many defeats," Christian Science Monitor, December 31, 2012.
} 
2007, Halliday 2007, Masoud 2008, Trager 2011).

However, as impressive as the Brotherhood's organizational structures and methods may seem to outside observers, there has never been a systematic exploration of the relationship between these practices and the Brotherhood's electoral success. Moreover, the results of recent Egyptian elections suggest that Islamist success is likely not solely (or even principally) attributable to such internal factors. For example, the Salafi party, Hizb al-Nūr-the second-most popular party in the 2011-12 parliamentary elections-does not apply the Brotherhood's organizational model. The pietist movement on which it is largely based, the Salafi Call Society (Jamā'at al-Da'wa al-Salafiyya), displays neither the Brotherhood's selectivity with respect to new members nor its cellular structure. On the whole, Salafi movements are far less routinized and bureaucratized than the Brotherhood, with the emphasis being on the individual's adoption of and adherence to orthodox practices (iltizām), rather than formal membership in an organization (Wiktorowicz 2001, Trager 2013). And though the Salafi movement's principal political party, Hizb al-Nūr, has a seemingly Brotherhood-like tiered membership structure and demanding criteria for promotion to higher levels within the party, this appears to be relatively standard practice among all Egyptian political parties. ${ }^{31}$ For example, the internal regulations of the secular Free Egyptians Party detail three levels of membership: the "friend of the party," "member," and "active member." To be an active member in the FEP, the recruit must undergo a probationary period of six months with at least 100 hours of voluntary service to the party ${ }^{32}$ It is unnecessary to point out that tiered membership, thought to be key to the Muslim Brotherhood's success, worked no similar effect for the FEP.

Another facet of the Islamists' supposed organizational superiority relates to how the they link to voters. Several scholars have noted that the Muslim Brotherhood in particular has won votes by providing goods, ranging from health care to free food, to indigent Egyptians (Kepel 1985, Tessler and Nachtwey 1998, Wedeen 2002). For example, during the March 2011 constitutional referendum (which was ostensibly intended to determine the country's course after Mubarak's overthrow), the Brotherhood was accused of distributing bottles of cooking oil and bags of sugar in an attempt to sway voters to vote in favor of a proposed package of constitutional amendments. ${ }^{33}$ During subsequent parliamentary elections in late 2011, in addition to providing the aforementioned goods, the Brotherhood's "charitable machine" reportedly opened shops to sell "discounted meat and vegetables" to cash-strapped families. ${ }^{34}$ On the second anniversary of the January 25th revolu-

\footnotetext{
${ }^{31}$ Al-lā'iha al-dākhiliyya li-ḥizb al-Nūr (internal regulations of the Nūr Party), Section 2, Articles 6 to 26. Available from author.

32 Al-Nizām al-asāsī li-hizb al-misriȳin al-ahrār (Statute of the Free Egyptians Party), Section 3 "'aḍā' al-hizb (party members)," especially articles 75 and $76 . \quad$ Available at: http://www.almasreyeenalahrrar.org/Rules/Statute.aspx

${ }^{33}$ Rāmī Nawwār, "Taqrīr huqūqī yarșud tawzī' al-Ikhwān al-zayt wa al-sukkar 'alā al-nākhibīn (Legal report details the Brotherhood's distribution of oil and sugar among voters)," al-Mișī alYawm (Cairo), March 19, 2011. Available at: http://www.youm7.com/News.asp?NewsID=372852

${ }^{34}$ Leila Fadel, "Muslim Brotherhood sells cheap food ahead of holiday and Egypt parliament
} 
tion, amid widespread demonstrations against President Morsi, the Brotherhood announced that it would organize a nationwide volunteer campaign to offer health services and school improvements. ${ }^{35}$ In one district, al-Haram in the governorate of al-Gīza, the Brotherhood's Freedom and Justice Party even offered free cram courses for secondary school students. ${ }^{36}$

Egyptian secularists so far do not appear to deploy a similar linkage strategy. As one liberal Egyptian party member lamented, "No party will succeed if they sit around and talk politics [...] which is what all the parties are doing except for the Muslim parties. What we should do is take the way that they are reaching the people and use it. We need to do what they're doing." 37 During the Mubarak era, Hamzawy and Ottaway complained that secular parties "neglected grassroots mobilization and constituency building for a long time," failed to develop "emotionally appealing, simple political slogans," and "have not developed the funding methods to sustain the staff required to carry out systematic organizing work." 38 In a July 2012 speech to the Carnegie Endowment for International Peace, a visibly exasperated secretary of state Hilary Clinton echoed the notion that the political marginalization of Egyptian secular parties was a function of their own organizational inadequacies:

"I am urging those who are concerned, not only Christians, but also moderates, liberals, secularists, to organize themselves. This is something that I started talking to the Tahrir Square veterans about shortly after the fall of Mubarak. It has been my experience that when democratic space opens up, when freedom opens up, with authoritarian regimes falling, those who are unorganized will not be successful." ${ }^{\prime 39}$

What accounts for the failure of secular and leftist parties to partake of the organizational strategy that has long been thought to bring Islamists such success? The first potential explanation is that many of these parties-such as the Social Democratic and Free Egyptians parties-are new, and thus lack electoral experience or well-developed internal structures. The Muslim Brotherhood, in contrast,

vote," Washington Post, November 5, 2011. Available at: http:/ /articles.washingtonpost.com/201111-05/world/35283999_1_muslim-brotherhood-eid-al-adha-new-party

${ }^{35}$ Muhammad Ismā'îl, "Mu'tamar saḥafī lil-ikhwān al-muslimīn litadshīn miliyuniya al-khadamāt al-thulathā' (Press conference to inaugurate a million-man service campaign" on Tuesday)," al-Yawm al-Sābi' (Cairo), January 20, 2013. Available at: http://www.youm7.com/News.asp?NewsID=915312

36 "Bi al-ṣuwar: al-Ikhwān tukathaf taḥarukātihā lilhashd fī intikhābāt albarlamān (In pictures: The Brotherhood intensifies its movements to mobilize in the parliamentary elections)," al-Mașrāwī, January 11, 2013. Available at: http:/ /www.masrawy.com/news/egypt/politics/2013/january/11/5487402.aspx

${ }^{37}$ Evan Hill, "Do Egypt's Liberals Stand a Chance," Foreign Policy, November 16, 2011

38 Amr Hamzawy and Marina Ottaway, "Fighting on two fronts: secular parties in the Arab world," Carnegie Papers, Carnegie Endowment for International Peace, No. 85, May 2007, p. 21. Available at: http://carnegieendowment.org/files/cp85_secular_final.pdf

${ }^{39}$ Speech by Secretary of State Hilary Rodham Clinton, "International Religious Freedom," Carnegie Endowment for International Peace, July 30, 2012. Available at: http://www.cspanvideo.org/program/307322-1 
has fielded candidates in every Egyptian election since 1984 (with the exception of an opposition-wide boycott in 1990). The Brotherhood's long history of electioneering, the reasoning goes, may have enabled it to build up organizational knowledge and experience that its newly-formed competitors necessarily lack. But though this argument is intuitively appealing, it cannot help us explain why secular parties with an equally extensive record of electoral participation-such as the NPUR and the Wafd (which in 1984 was deemed by the Muslim Brotherhood's general guide, 'Umar al-Tilmissānī $(1985,184)$ to have "more of a popular base" than other parties) - performed so poorly in elections before and after Mubarak's overthrow. Nor can it help us to explain why the Salafi Nūr party, founded in May 2011 and an electoral novice, was so quickly able to emerge as the second largest bloc in parliament.

The second potential explanation for the secularists' alleged inability to organize, and the one most often encountered in both the literature and the prodigious political commentary on this issue, is that non-Islamists simply lack strategic acumen. For example, a leading Egyptian jurist recently accused the Brotherhood's secular opposition of suffering from "political stupidity." ${ }^{40}$ In 2005, after the Muslim Brotherhood captured 88 of 444 seats in the Egyptian parliament (while non-Islamist opposition parties captured a total of nine), a U.S. embassy dispatch declared that the secular opposition parties were "done in by their ineptitude." ${ }^{11}$ Carothers and Ottaway (2004) tell us that secular parties possess "little capacity - and less inclination - to translate abstract ideas into programs with mass appeal," and "talk to Western organizations and each other more than to their fellow citizens" - a bad strategy for winning elections. Almost twenty years ago, the Egyptian scholar Moheb Zaki $(1995,98)$ wrote that the weakness of secular opposition parties during the Mubarak era was "a consequence of their political incompetence and lack of realism."

Of course, without being able to conduct psychometric tests on members of different parties, we cannot know whether there are in fact differences in the intelligence and strategic sophistication of party leaders (let alone whether these differences, if measurable, can explain differences in party behavior). But it is difficult to take this notion seriously. If parties behave differently, it seems more reasonable to begin from the assumption that they do so because they face different opportunity and incentive structures, not because their leaders have different cognitive capacities. Though activists and political pundits may be frustrated by the fact that leftist and liberal parties do not copy the Islamist playbook, it may be that these parties' failures are less due to stupidity or short-sightedness than to factors that reside beyond their control.

\footnotetext{
${ }^{40}$ Sayyid Aḥmad, “Ra'îs mahkama al-isti'nāf: al-mu'āraḍa tu'ānī min ghabā' siyāsī (Chief of the appeals court: The opposition suffers from political stupidity)," al-Dustūr (Cairo), December 9, 2012.

41 “2005 in Egypt: Serious Change Raises Serious Resistance," U.S. Embassy, Cairo, Egypt, December 15, 2005, available at: http:/ / wikileaks.org/cable/2005/12/05CAIRO9314.html
} 


\section{Opportunity structures}

In this article, I argue that if parties of the left have been less successful than Islamists at generating linkages to voters-whether these be programmatic or clientelistic (Kitschelt 2000) - it is not because they are feckless or otherwise deficient, but because they face fewer opportunities for doing so than do Islamist parties. As Desai $(2002,624)$ points out, political parties in new democracies "are presented with structurally defined possibilities" that include "prior forms of association [and] preexisting networks of social action." These pre-existing forms of collective activity can be powerful resources for political parties in newly democratizing systems. Given the compressed time period between autocratic collapse and a country's founding elections-in Egypt, it was a mere 10 months-a party faces the challenge of generating the kinds of linkages that will enable voters to recognize its policy stances and trust that it will implement them if elected to office. But establishing the institutions of linkage-such as base units, social service operations, community centers, and the like-is both costly and time-consuming. As a result, the more embedded a party —or, more accurately, its members-within prior forms of association, the greater its potential for capturing the votes of similarlyembedded citizens.

But this task is not as simple as finding out where voters associate and preaching the party's word there. Embeddedness is not something that can be generated instantly, and is not necessarily even the result of purposive strategies by party leaders. Instead, a party's embeddedness in forms of associational life emerges organically from the affiliation decisions of party activists. The type of individual likely to join the Muslim Brotherhood is also the type who is likely to donate some of his spare time to a local Islamic charity or to regularly attend the mosque. His advancement within the Brotherhood may even be predicated in part on such displays of community involvement and influence. During the authoritarian period, the Brotherhood activist's embeddedness in religious networks was of only limited electoral utility, as voter turnout was low, and religious associations assiduously avoided the kinds of politicization that could invite unwanted regime attentions. But with the advent of more open political competition, Islamist parties found themselves with a fund of linkages that Egypt's leftists, who had no analogue to the dense networks of faith-based institutions, could not match.

In this section, I describe the Egyptian associational ecosystem and show how, due to a combination of actions of the authoritarian state and organic processes of development, it is dominated by traditional forms of civic life rooted in faith and the family, with little space for social organizing on the basis of class or occupation. I then describe how this skewed civic landscape redounds to the benefit of Islamist parties during the country's founding elections, leaving parties of the left at a particular disadvantage. 


\subsection{Kith and kin}

The associational landscape that Egyptian political parties face is a mixture of formal and informal institutions and networks. Among the most prominent are those based on family and locality, particularly in rural areas (al-Munūfī 1980; 'Abd alMajīd and Mus'ad 1992; Bin-Nafīsa and 'Arafāt 2005; Lust-Okar 2006). As Brown $(1990,112)$ writes in his pathbreaking study of peasant collective action in early twentieth century Egypt: "The family, very broadly defined, often formed the community involved in an action. From most accounts of incidents, it is clear that individuals often received the support not only of household members and close relatives but also scores, even hundreds of relatives (close and remote), friends, and associates (generally referred to as ansar in the newspaper accounts)." Though many of these informal networks of kith and kin were disrupted by agrarian reforms in the 1950s that broke up large landholdings and with it much of the power of the old landed families (Ansari 1986), and by steady migration to the cities, local loyalties appear to remain strong. Watts (1993) notes that "the importance of the lineage, the family and clientage is felt at all levels of society. [...] At the provincial and local levels, local notables, as reformed in the years after the 1952 revolution, have been able to act as intermediaries between ordinary people and the state." For example, during the Mubarak era, being a "son of the village (ibn al-qarya)" was an important electoral credential (Rabi' 1997, Bin-Nafisa and 'Arafat 2005), and Blaydes (2006; 2010) and Shehata (2008) have described how the former ruling National Democratic Party tapped into networks of local notability in order to recruit parliamentary candidates to run on its slate.

Though the 2011 Egyptian revolution was in part a revolt against the clientelistic politics of the Mubarak era, there is evidence of the resurgence of such politics during the 2011 parliamentary elections. Political parties of all stripes attempted-with varying degrees of success-to harness local loyalties and networks. For example, the Wafd Party nominated on its slate a woman named Sahar Țal'at Musțafā, who was the sister of NDP-tycoon and former upper house member Hishām Ṭal'at Mustafā, and presumably possessed of a large retinue of retainers whose votes could be brought over to the party. ${ }^{42}$ Similarly, in the district of Qalyūb in the governorate of al-Qalyūbiyya, the Muslim Brotherhood's Freedom and Justice Party nominated Muhammad Hāni, the scion of a large family in the district and the son of a former high ranking official of the National Democratic Party. ${ }^{43}$ In the districts of the Southern Sinai, which are dominated by bedouin tribes—such as the Huwayțāt, Qararsha, and 'Alayqāt-several parties sought to capture tribal votes by putting tribe-members at the top of their electoral lists. ${ }^{44}$

\footnotetext{
${ }^{42}$ Aḥmad 'Abd al-Jalīl, "Al-Aḩzāb tuṭāib bil-'azl al-siyāsīl wa turashah fulūl al-waṭanī 'alā qawā'imuhā (The parties call for political exclusion while nominating the leftovers of the National Democratic Party on their electoral lists)," Al-Fajr (Cairo), October 15, 2011. Available at: http:/ / www.elfagr.org/dailyPortal_Print_News_Details.aspx?nwsId=69866\&secid=1

43 'Īd 'Abd al-Jawād, "Kubrā al-'ā'ilāt al-barlamāniyya bil-Qalyūbiyya tughīb 'an al-intikhābāt (The biggest parliamentary families in al-Qalyūbiyya are absent from the elections)," al-Misrī alYawm (Cairo), December 12, 2011. Available at: http:/ / www.almasryalyoum.com/node/575811

${ }^{44}$ Nabīl Siddīq, "Qabā'il al-Mazīna wa al-Qararsha wa al-'Alayqāt wa al-Jibāliyya wa al-
} 
During the presidential elections, Sinai tribal leaders emerged as key power brokers, as several presidential candidates made pilgrimages to seek their endorsements (and their vote banks). ${ }^{45}$ In the upcoming parliamentary elections-which are, as of this writing, scheduled to conclude in the summer of 2013-the Southern Sinai branch of the Brotherhood's Freedom and Justice Party has already signaled its intention to nominate candidates from the tribes of al-Mazina and al-Hamāda. ${ }^{46}$

Though bloc voting by families and clans have been consequential in Egypt's founding elections-particularly outside of the country's urban core-there are three reasons to believe that the importance of such voting was diminished when compared to earlier elections. First, the stigma of former association with the ruling party appears to have prevented many local notables from running in the first elections after Mubarak's fall. For example, in the district of Shubrā al-Khayma outside of Cairo, the 'Awda family, which typically fielded candidates in parliamentary elections, abstained in 2011, as the family's principal political personality, Muhammad 'Awda, a member of the 2010 parliament, faced charges of helping to organize attacks against protesters in Tahrir square. ${ }^{47}$ (It is worth noting, however, that the stigma of association with the NDP appears to have a short half-life, as evidenced by the $48 \%$ of the vote captured by former Mubarak-era official Ahmad Shafiq in the second round of the 2012 presidential election.)

Second, even where local notables did run, the drying up of their access to sources of patronage-such as public sector jobs for constituents, or expedited health and social services from the relevant government ministries-likely diminished their electoral prospects. For example, in the district of al-Zaqāzīq in alSharqiyya, former NDP-affiliated candidates with long records of service provision to their home villages-including three-time parliamentarian Luṭī Shahata of the village of Banī Shibl and six-time parliamentarian and minister of transportation official 'Izzat Badawī-all fared poorly at the polls, while two-time NDP representative Rif'at al-Bayūmī (1990-2000) withdrew his candidacy shortly before election day. ${ }^{48}$ Stripped of the promise of preferential entrée to the patronage resources of

Huwayțāt tatașāri' 'alā 6 maqā'id bi-junūb Sīnā' (The tribes al al-Mazina, al-Qararsha, al-'Alayqāt, al-Jibāliyya, and al-Huwayțāt wrestle for 6 seats in South Sinai)," al-Ahram (Cairo), December 26, 2011

${ }^{45}$ Nāṣir Abū Ṭahūn, “Qabā'il junūb Sīnā' tubaya' Musa ra'isan limisr wa 'ahad shuyukhiha yaqul lahu utalibuk bi-'an taqtadi bisayyidna Musa (The tribes of Southern Sinai pledge allegiance to Musa for president of Egypt and one of their leaders says to him, I ask you to emulate the prophet Moses)," al-'Arabì (Cairo), February 24, 2012; Maryam 'Abd Allāh, "Hal yahṣud Mursi aṣwāt qabā'il Sīnā'? (Has Morsi harvested the votes of Sinai's tribes?)," al-Dustūr (Cairo) May 26, 2012; Huda alMisri, "Qabā'il Sīnā' yastabdilun 'Amr Musa bida'm Ahmad Shafiq (The tribes of Sinai trade Amr Musa for Ahmmad Shafiq)," Rose al-Yūsuf (Cairo), June 16, 2012

46 "Al-Hurriya wa al-'adalah ya'lan qa'ima murashahih li-intikhābāt al-nuwwab bijunub Sina wa al-Nur yarfud al-tansiq ma'hum (Freedom and Justice announces its nominees for elections to the Chamber of Deputies in Southern Sinai, and al-Nur refuses to coordinate with them)," al-Mashhad (Cairo), January 8, 2013. Available at: http:/ /al-mashhad.com/Articles/145893.aspx

47 'Īd 'Abd al-Jawād, "Kubrā al-'â'ilāt al-barlamāniyya bil-Qalyūbiyya tughīb 'an al-intikhābāt (The biggest parliamentary families in al-Qalyūbiyya are absent from the elections)," al-Misrī alYawm (Cairo), December 12, 2011.

${ }^{48}$ See Rūḥ al-Fu'ad Muhammad, "Al-intikhābāt bidawā'ir al-Sharqiyya (Elections in the dis- 
a one-party state, many a local notable proved not notable at all.

Third, the electoral rule chosen by Egypt's interim military rulers may have made it more difficult for local personages to get elected. From 1990 to 2010, Egypt employed a highly candidate-centric system with 222 two-member electoral districts. Each election featured several thousand candidates, the vast majority of whom were independents without party labels. As several observers have noted, this system encouraged the cultivation of personal votes (Carey and Shugart 1995) based on a candidate's ability to provide clientelistic benefits to his home district (Blaydes 2010). After Mubarak's overthrow, secular political parties lobbied for a shift to an electoral system based on proportional representation and closed party lists, as they felt this would diminish the power both of old regime elites and Islamists (the two groups that had dominated under the old system). Sāmih 'Āshūr, the leader of the Nasserist Party and the former head of the Lawyers Syndicate, declared that "only the Muslim Brotherhood and the National Democratic Party want to keep fardi (candidate-centric) seats," and that only proportional lists would "ensure representation of all political and national forces in the parliament." 49 In the end, the military issued a compromise electoral law in which two-thirds of the parliament's 508 elected representatives would be elected on closed party-lists in 46 multi-member districts, with the remaining third to be elected according to the old fardi candidate-centric system. ${ }^{50}$ Though secular parties opposed the retention of the fardi tier, the fact that each constituency was now 2.6 times larger than under the previous system would diminish the importance of all but the largest local vote banks. ${ }^{51}$

\subsection{Islamic institutions}

If family and clan loom large in the informal associational landscape of Egypt, the formal space has long been marked by a proliferation of religious institutions. ${ }^{52}$

tricts of al-Sharqiyya)," Jarīdat Akhbār al-'Iliktrūniyya (Cairo), December 5, 2011. Available at: http://akhbar.masreat.com/7581/; Imān Mahanna, "Insihāb 4 murashahīn bi al-Sharqiyya baynahum nā'ib sābiq bi al-munhal (Withdrawal of 4 candidates in al-Sharqiyya including a former deputy of the dissolved [NDP])," al-Yawm al-Sabi' (Cairo), December 7, 2011.

49 Mahmud Sa'd al-Dīn and Maḥmud Husayn, "Al-Ikhwān yarfiḍūn mashrū' qanūn majlis alsha'b alathi 'a'adahu al-majlis al-'askari wa yasifūnahu bitashwih nizam al-intikhābāt (The Muslim Brothers refuse the draft People's Assembly election law prepared by the Supreme Council of the Armed Forces and describe it as ruining the electoral system)," al-Yawm al-Sabi' (Cairo), May 28, 2011

${ }^{50}$ Qanun raqam 120 lisanat 2011 bita'dil ba'd ahkam al-qanun raqam 38 lisanat 1972 bi sha'n majlis al-sha'b (Law 120 of 2011, mending some of the rulings of law 38 of 1972 concerning the People's Assembly), September 27, 2011

51 'Amr al-Shubaki, an Egyptian analyst and member of the now-dissolved 2012 People's Assembly, has proposed an electoral system with much smaller single-member districts, in part to increase the importance of candidates' personal connections to voters. See, 'Amr al-Shubaki, "Nahw qanun jadid lil-intikhābāt al-barlamaniyya (Toward a new parliamentary elections law)," al-Misrī al-Yawm (Cairo), January 2, 2013

52 This is in contrast to predominantly tribal societies like Jordan, where formal tribal or family associations (jam'iyyāt ' 'a'iliyya), registered as private voluntary organizations, exist in significant 
Fig. 6: Mosques by Governorate

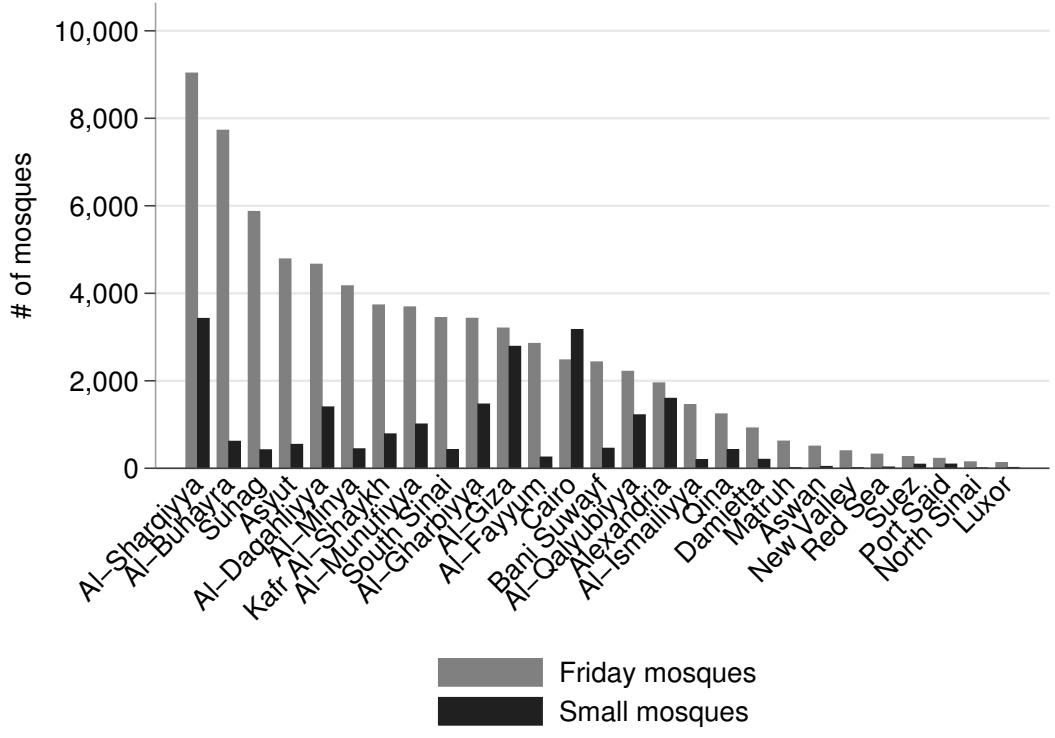

For example, Western chroniclers of Egypt have for centuries noted the ubiquity of mosques in that land. ${ }^{53}$ The great Orientalist Edward William Lane wrote in his 1836 Account of the Manners and Customs of the Modern Egyptians that "the mosques of Cairo are so numerous, that none of them is inconveniently crowded on the Friday." 54 Though Lane's observation about the capaciousness of Cairo's mosques no longer holds true-Friday prayers in most urban mosques are routinely crowded, and worshippers often spill out onto a mosque's surrounding streets-his description of their great number remains accurate. Figure 6 displays the number of mosques in Egypt as of 2006, broken down by governorate and type of mosque"Friday mosques" (jawāmi', singular jāmi') are those large enough to conduct congregational prayers on Friday and are administered by the Ministry of Religious Endowments; "small mosques" or (zawāy $\bar{a}$, singular zawya), are prayer rooms usually established by locals. As of 2006, there were 71,931 Friday mosques, and 21,118 small mosques in Egypt, for an average of one mosque for every thousand inhabitants.

Scholars have hypothesized that mosques served an important political role in the authoritarian Middle East. According to Wiktorowicz (2004) and Munson

number. See Baylouny (2010).

${ }^{53}$ See, for example, James Menzies, History of the Late Expedition to Egypt, under the command of Lieutenant General Sir Ralph Abercrombie, E. Miller (Glasgow), 1803, p. 85; Josiah Conder, The Modern Traveller: A Popular Description, Geographical, Historical, and Topographical, of the various countries of the Globe, Volume 1: Egypt, Nubia, and Abyssinia, James Duncan (London), 1827, pp. 271-72; Stanley Lane-Poole, The Art of the Saracens in Egypt, Librairie Byblos (Beirut), 1886, p. 7

${ }^{54}$ Edward William Lane, An Account of the Manners and Customs of the Modern Egyptians: Written in Egypt during the years 1833, 34, and 35 partly from notes made during a former visit to that country in the years 1825, 26, 27, and 28, Volume 1, John Murray (London), 1871, p. 100 
(2001, 502), authoritarian repression of political activity meant that mosques became the only arenas in which people could gather and exchange information about their plight, rendering them natural focal points of dissent. ${ }^{55}$ Eventually, however, autocrats worked to close off mosques as well. During the Mubarak era, mosques were frequently shuttered between prayer times in order to bar political gatherings; electioneering and campaigning in mosques and churches was prohibited by law; ${ }^{56}$ and local imams (who are employees of the Ministry of Religious Endowments) and other mosque workers frequently enforced these prohibitions lest they jeopardize their own jobs. Usāma Darra (2011, 30-31), a young Muslim Brotherhood member (who left the group in 2011), wrote that the movement's antagonistic relationship with the Mubarak regime caused it to "lose the mosques." Due to regime crackdowns, he wrote, "we practiced our calling in the eye of a needle, and some of our youth would have killed to be able to say a brief word after 'asr (late afternoon) prayers in a small zawya in a remote village."

After the revolution, however, restrictions on the political use of mosques loosened considerably. For example, press accounts of the campaigns of Muslim Brotherhood and Salafist parliamentary candidates often note that they involve visits to local mosques, where they often give formal sermons. A typical example is the FJP's report of the activities of two of its newly-elected parliamentarians from al-Fayyum-Hamdī Taha and Ahmad Ibrahīm 'Uḍwī: "The tour of the two deputies began with Friday prayers, in which Ahmad Ibrahim gave the sermon in the mosque of Masākin Birnis while Hamdi Taha gave the sermon in the mosque of the village of 'Ank. ${ }^{57 "}$ In contrast, I could find no reports of non-Islamist candidates visiting or giving speeches in mosques. The Wafd Party's newspaper featured a solitary report that criticized a Brotherhood candidate in North Sinai in 2010 for merely "contenting himself with offering each prayer in a different mosque and meeting the voters after each prayer." 58

Egypt's mosques may seem like timeless features of the natural environment, but a large proportion are the product of efforts of private donors, volunteers, and Islamic charitable associations (jam'iyyāt khayriyya islāmiyya). ${ }^{59}$ The latter make up

\footnotetext{
${ }^{55}$ See also Bertus Hendriks on the political role of mosques in contemporary Iraq, "Iraq: The Complexities of an Artificial Nation," Radio Netherlands, January 27, 2005, http:/ / www.radionetherlands.nl/currentaffairs/region/middleeast/irq050127

56 Article 11, Law 38 of 1972 on the People's Assembly, Arab Republic of Egypt, July 2005

${ }^{57}$ Mansur Sa'dawi and Mahmud Salah al-Din, "Nuwwab al-Huriyya wa al-'Adala bil-Fayyum yu'akaddun mas'uliyatihim tijah al-jamahir (The deputies of the Freedom and Justice Party in al-Fayyum affirm their responsibility toward the voters)," www.hurryh.com (Freedom and Justice Party official website), December 17, 2011. Available at: http://www.hurryh.com/Provinces/PartyActive_Details.aspx?News_ID=6771\&ID=26

${ }^{58}$ Khalid al-Sharif, "Ihbat wa 'uzuf 'an al-intikhābāt fi al-'Arish (Depression and abstention from elections in al-Arish)," al-Wafd (Cairo), November 25, 2010.

${ }^{59}$ Mosques are regulated by the Ministry of Religious Affairs, which places strict conditions on the building of new ones. See Ahmad 'Abd Allāh, "Wazir al-'Awqaf al-Misri: Dawabit bina' almasajid al-jadida hadafuha waqf iqamat al-zawāyā wa bina' masajid hadariyya (Egyptian Minister of Religious Endowments: The goal of the guidelines for building new mosques is to halt the establishment of zawāyās and promote building modern mosques)," al-Sharq al-Awsat, March 9, 2002. Available at: http:/ / www.aawsat.com/details.asp?article=92180\&issueno=8502\#.UT1AJtF4grg
} 
the plurality of private voluntary associations in Egypt, constituting what Wickham (2002) has referred to as a "parallel Islamic sector." According to Kandil (2004), these associations have a long history in Egypt, and are a natural outgrowth of Islamic traditions of almsgiving through zakāt (an obligatory $2.5 \%$ tax on savings) and șadaqa (voluntary acts of charity). The first such association, appropriately named the Islamic Charitable Society (al-Jam'iyya al-Khayriyya al-Islämiyya), was established in 1878 and, in addition to maintaining branches throughout the country, continues to operate a large hospital in al-'Agüza section of greater Cairo. Perhaps the most well-known Islamic charity is the grandly named Legitimate Society for the Cooperation of those who work by the Book and Muhammadan Traditions (al-Jam'iyya al-shar'iyya li-ta'āwun al-'āmilīn bil-kitāb wa al-sunna al-Muhammadiyya, henceforth abbreviated JS), which was established in 1912, and which currently has almost 5,000 local units, ranging from clinics to Qur'anic study centers to preacher training institutes to daycare centers, and which provides yearly support for almost half a million orphans.

There are also a large number of smaller, local associations such as Islamic Association for Complete Services, Happiness, and Cooperation (al-Jam'iyya alIslāmiyya lil-khadamāt al-shāmila wa al-sa'äda wa al-ta'āwun), located in the town of Shubrā al-Khayma just north of Cairo, which offers a medical clinic, kindergarten, support for orphans, Qur'anic lessons, and a mosque. Figure 7 shows the share of private voluntary organizations, as of 2007 , that are Islamic, broken down by governorate. The data is drawn from a comprehensive database of more than 17,000 private voluntary organizations maintained by the Ministry of Social Affairs in 24 governorates. ${ }^{60}$ I code an association as "Islamic" if it has the words "Islām," "Sunna," "Qur'ān," "Muhammad," "Allāh," "Muslim" or "Masjid" in its name; or if its official description on file with the Ministry indicates that it is Islamic, involved in teaching the Qur'an, or in building mosques; or if its postal address indicates that it is housed at a mosque. In more rural governorates, such as al-Munufiyya and al-Sharqiyya in the Nile Delta, the percentage of private voluntary organizations with Islamic characteristics approaches $50 \%$. Overall, Islamic organizations account for approximately $20 \%$ of the nationwide total.

Islamic charitable associations are often treated in the literature as the creation of Islamist movements for clientelistic purposes (see, for example, Berman 2003), but the reality is more complex. Though Islamist politicians may have found it in their interest to suggest that the Islamic charitable sector is a function of their efforts-'Abd al-Mun'im Abū al-Futūh, a former member of the Brotherhood's governing body (maktab al-irshäd or guidance bureau) testified in 2006 that the entirety of the Islamic social services sector belonged to the Muslim Brotherhoodthe vast majority of such associations were apolitical (Wickham 2003). ${ }^{61}$ And when Islamic charities were bent to political aims, it was as often by the ruling party as

${ }^{60}$ I was not able to obtain the data for the governorate of al-Fayyūm (population 2.7 million).

61 "Egypt: Social programmes bolster appeal of Muslim Brotherhood," Integrated Regional Information Networks News Service, United Nations Office for the Coordination of Humanitarian Affairs, February 22, 2006 (available at http:/ / www.irinnews.org/report.aspx?reportid=26150, last accessed March 20, 2008) 
Fig. 7: Proportion of private voluntary organizations that are Islamic, by governorate, 2007

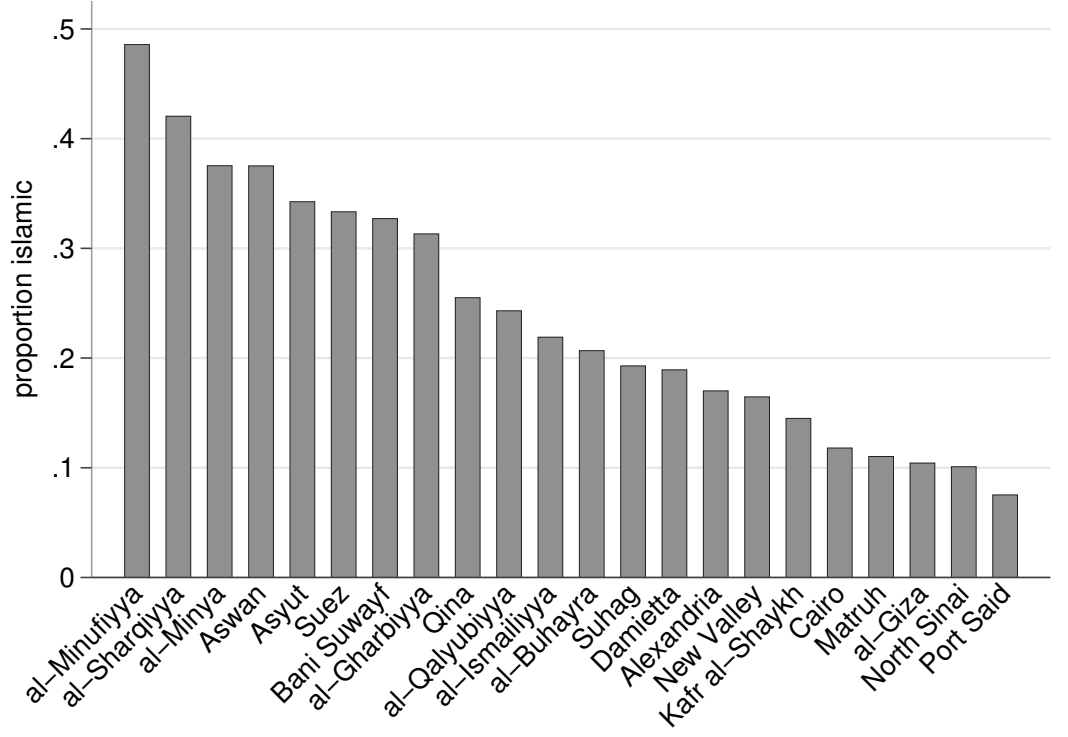

much as the Brotherhood. For example, in 2005, Mahmūd Khamīs, a ruling party candidate in the district of Bilbays in al-Sharqiyya-and the brother of a floor coverings tycoon-had secured the endorsements of several Islamic associations with hefty donations. One of these, Jam'iyyat al-Khayr al-Islämiyya (The Islamic Society of Plenty) in neighborhood \#15 of 10th of Ramadan City, even figures in one of Khamis's campaign flyers, which featured a photo of the candidate seated on a dais with leaders of the association. In December, 2007, the independent Egyptian newspaper al-Misri al-Yawm published an exposé on the use of public funds by NDP deputies to pay for charitable projects in their home districts, revealing that a number of the ruling party's deputies dispensed funds through local Islamic associations. $^{62}$

The same is true of Egypt's largest Islamic association, al-Jam'iyya al-Shar'iyya (JS), which is often incorrectly treated as an auxiliary of the Muslim Brotherhood. As one report in the (admittedly anti-Brotherhood) magazine Rose al-Yūsif put it, "as for the Jam'iyya al-Shar'iyya, it is well known that it is the mother that long cradled the idea of the Society of Muslim Brothers, for it was founded along with the Muslim Brotherhood at the same time." 63 But, as Bin-Nafīsa and 'Arafāt $(2005,213)$ pointed out during the Mubarak era, "Sometimes the presidents of local branches

\footnotetext{
62 “Bi al-mustanadāt wa al-arqām: Al-Misrī al-Yawm takshif tafāsīl rashāwī al-hukuma li nuwwāb al-Watanī (With documents and numbers: al-Misrī al-Yawm exposes government bribes to the deputies of the National Democratic Party)," al-Misrī al-Yawm, December 10, 2007. Available at http:/ / www.almasry-alyoum.com/article2.aspx?ArticleID $=85878$

63 'Isam 'Abd al-Jawwad, "La'bat shad habl bayn al-Salafiyin wa al-Ikhwān li-Istiqtab 8 malayin sawt min Ansar al-Sunnah (Tug of war between the Salafis and the Brothers to capture 8 million votes from Ansar al-Sunnah)," Rose al-Yūsif (Cairo), October 25, 2011.
} 
of the Jam'iyya are members of the National Democratic Party." For example, 'Adil Abu Sulayb, an unsuccessful candidate in the 2005 and 2010 elections, was both the president of his local branch of the JS (in the Giza district of al-Haram) and a local secretary of the National Democratic Party. ${ }^{64}$ In 2011, he ran for parliament again and won-this time on the banner of the Nūr Party. ${ }^{65}$ What all of this suggests is that we can no more endogenize the Islamic charitable sector to the Muslim Brotherhood than we can attribute the Salvation Army to the Republican Party ${ }^{66}$ It is instead more accurate to think of religious associations such as the JS-which, after all, predates the founding of the Muslim Brotherhood by 16 years-as pre-existing forms of social life that political parties attempt to tap into, but whose existence is largely independent of those parties.

Just as the collapse of the ruling party made it possible for political parties to compete for the allegiances of local notables and family blocs, so too did it increase the space for parties to try to link to voters through religious institutions. And in this, Islamists had a natural advantage-not because they "owned" the "parallel Islamic sector," but because they were embedded in it. Perusing the biographies of Muslim Brotherhood parliamentary candidates in recent elections is like reading a directory of Islamic social organizations-in addition to membership in the JS, Brotherhood candidates claimed membership in al-Jam'iyya alTarbawiyya al-Islāmiyya (Islamic Training Association) in al-Gharbiyya governorate, Jam'iyya al-Muwāsa al-Khayriyya al-Islāmiyya (al-Muwāsa Islamic Charitable Society) in al-Munufiyya, Jam'iyya al-Risāla al-Khayriyya (The Message Charitable Society), Jam'iyya al-Diā' al-Khayriyya (The Luminance Charitable Society), to name just a few. As 'Abd al-Wahhāb (2011) has written,

"Many of the Brotherhood candidates who won maintained deep relationships with branches of these associations in their electoral districts. There are some who gave sermons in its mosques, or who supervised or participated in overseeing some of its charitable social projects, or who took on important roles in its zakāt collection committees, and though these associations, candidates linked to scores of hospitals and clinics and orphanages and literacy programs and training sessions and social centers."

\footnotetext{
${ }^{64}$ Ahmad Jamal, "Nakhibu al-Giza: Lan nasmah bi'awdat al-fulūl (Voters of al-Giza: We will not permit the return of the remnants)," Ikhwān Online, December 10, 2011. Available at: http:/ / www.Ikhwanonline.com / Article.aspx?artid=96942\&secid=250.

${ }^{65}$ Abu Sulayb died shortly after his election, and without ever having taken his seat. See Mahmud Ramzi, "Wafat Abu Sulayb, na'ib Hizb al-Nur 'an da'ira Shimal al-Giza (Death of Abu Sulayb, parliamentary deputy of the Nūr Party for the district of North Giza)," al-Misrī al-Yawm (Cairo), December 20, 2011; and Ahmad Abu Salih, "Wafat 'udw majlis al-sha'b 'Adil Abu Sulayb (Death of People's Assembly Member 'Adil Abu Sulayb)," al-Wafd (Cairo), December 20, 2011.

66 This despite the fact that the Salvation Army (founded 1865) espouses conservative social positions. The organization's International Moral and Social Issues Council has issued positional statements on such issues as gambling, Sabbath observance, and abortion that align it with the most conservative elements of the American political landscape. See Salvation Army, International Social Justice Commission: http://www1.salvationarmy.org/IHQ/www_ihq_isjc.nsf/vw-dynamicindex/0DE8368F450505098025761B00653CEB?openDocument
} 
Though the embeddedness of Islamist activists in Islamic social organizations and institutions meant that they and their parties were more likely to be able to reach out to voters through these institutions than their secular rivals, it also meant that they had to compete with each other within those organizations. For example, during the 2011 parliamentary campaign, the (admittedly anti-Islamist) publication Rose al-Yüsif described a "tug-of-war" between the Muslim Brotherhood and the Salafists for the votes of members of Egypt's largest Islamist associations. For example, though the Muslim Brotherhood may have wished to monopolize organizations such as the JS, Nūr party candidates reportedly "had a great deal of credit with the members of al-Jam'iyya al-Shar'iyya due to the fact that many members of al-Da'wa al-Salafiyya would frequent its mosques. ${ }^{\prime 67}$

\subsection{Non-religious associations}

As noted earlier, Islamic associations make up approximately twenty percent of the formal associational landscape in Egypt. This means that the majority of associations are not religious in nature, and therefore-hypothetically, at least—available for mobilization by secular actors. For example, approximately $18 \%$ of the total number of private voluntary organizations registered with the Ministry of Social Affairs in the 2007 database are community development associations (Jam'iyyāt Tanmiyat al-Mujtama' al-Mahalī). These associations (henceforth abbreviated CDAs), exist in nearly every village and community in Egypt and offer a variety of services, from literacy classes to micro-credit loans to aid for the poor. Did CDAs embed non-Islamist politicians and activists? And if so, why did they-judging by the poor performance of secular parties in the 2011 parliamentary elections-not provide effective linkage to voters?

The answer is that, despite their impressive number, Egypt's CDAs neither embedded significant numbers of secular and leftist activists nor encompassed many voters. As one writer put it, "In every village and town in Egypt there are associations bearing the name 'Community Development Association,' but they are completely divorced from what we understand as development, as corruption has nestled within them throughout the years of the old regime." Though these associations were ostensibly responsible for "encouraging small projects, developing trade and craft skills among youth and girls, innovating creative social activities," instead they functioned as "family concerns whose members were limited to relatives" of CDA chairmen. ${ }^{68}$ The feeble nature of CDAs is in part attributable to the fact that they were more auxiliaries of the state bureaucracy than genuinely independent organizations. Ali al-Musailhy, the former minister of social affairs, in 2010 declared that CDAs "come under the scope of the general policy of the state and the strategy of the ministry to develop local communities and increase

\footnotetext{
67 'Isam 'Abd al-Jawwad, "La'bat shad habl bayn al-Salafiyin wa al-Ikhwān li-Istiqtab 8 malayin sawt min Ansar al-Sunnah (Tug of war between the Salafis and the Brothers to capture 8 million votes from Ansar al-Sunnah)," Rose al-Yūsif (Cairo), October 25, 2011.

${ }^{68}$ Sa'id al-Shahhat, "Jam'iyyat tanmiya al-mujtama' al-mahali fi 'asr al-thawra (Community Development Associations in the age of revolution)," al-Yawm al-Sabi', April 4, 2011
} 
popular participation, alongside governmental efforts to determine the needs of local communities and provide the necessary resources for the implementation of development projects." ${ }^{\prime 69}$

The para-statal nature of CDAs is unsurprising when one considers that they actually emerged out of a 1940s government program to establish rural social centers to combat illiteracy, disease, and "raise the standard of living in the Egyptian village in general."70 According to Sullivan $(1994,36)$, the government's role in the genesis of the CDA's has given them a decidedly semi-official character-they are often administered by public officials, receive funding from the Ministry of Social Affairs, and are generally perceived as "more of a public institution" than their religious counterparts. ${ }^{71}$

The state's dominance of the CDAs is an example of a broader phenomenon, which is the state's co-optation or absorption of many secular forms of organization (Jamal 2007). For example, we might have expected labor unions to be a primary avenue for the development of linkage by leftist parties. But although informal labor activism at the firm level has been a feature of daily life in Egypt for the better part of a decade (Rutherford 2008, 227-29), the government-controlled General Federation of Egyptian Trade Unions (al-Ittihhād al-'ām li-niqābāt 'ummāl Mișr) is technically the country's only legal union, and it has generally worked to mute, not encourage, collective action. ${ }^{72}$ Figure 8 shows membership in the trade union federation, broken down by governorate, toward the end of the Mubarak era. Though membership in the union is mandatory, only around $12 \%$ of the Egyptian labor force was unionized, reflecting not only the effects of regime control, but also the country's relatively small industrial base, and the large informal sector, variously pegged between $40 \%$ and $60 \%$ of the labor force (Beinin 2012; El-Fattah 2012).

Other forms of occupation-based associational life are equally weak and coopted by the state. For example, Egypt has more than 7,000 agricultural cooperatives, but these were essentially integrated into the state bureaucracy following the 1952 Free Officers coup (Pripstein-Posusney 1997, Bianchi 1986). Today, they are little more than "government controlled entities whose main function was to transmit government instructions about planting, marketing, and credit" (Brinkerhoff, et al 2002,30). And though workers and government employees have in some instances self-organized and established associations that are genuinely independent of the state, these are relatively few in number. Figure 9 compares the share of private voluntary organizations made up of mutual aid societies based on em-

69 "Al-Musailhy: 6898 jam'iyya li-tanmiyat al-mujtama' al-mahali fi misr (Al-Musailhy: [There are] 6898 community development associations in Egypt)," al-Misri al-Yawm (Cairo), November 15,2010

${ }^{70}$ Social Welfare in Egypt, Ministry of Social Affairs, Royal Government of Egypt, 1950, p. 11

${ }^{71}$ In recent years, employees of CDAs have petitioned the ministry of social affairs for higher wages and permanent contracts. Ashraf Kamal, "Ihtijaj muwazafi tanmiyat al-mujtama' lilmutalaba bil-tathbit (Protest of Community Development employees asking for permanent contracts)," al-Wafd (Cairo), July 22, 2012

72 Though in 2009 and 2010 the Ministry of Manpower recognized independent unions for real estate tax workers, teachers, and health care technicians (Beinin 2012, 5), these unions remain in violation of law 35 of 1976 which stipulates that all unions must be part of the GFETU. 
Fig. 8: Labor Union Density by Governorate, 2006

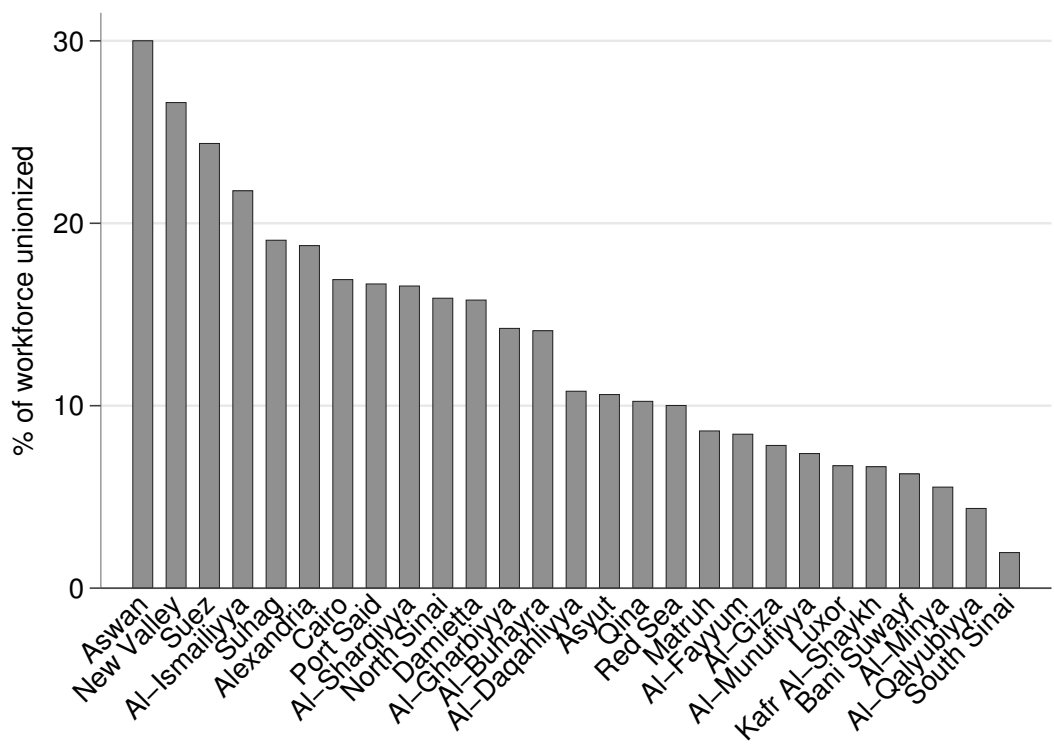

ployment or occupation (such as retirees associations or mutual benefit societies for tradesmen) to both religious associations and CDAs. The picture is one of a civic landscape dominated by faith on the one hand, and an overweening authoritarian regime on the other.

What all of this means for activists of leftist parties is that they possess few organic means of linking to potential constituents. And though the collapse of the old regime may provide hope for a resurgence of organized labor in Egypt that could reinvigorate parties of the left, it is likely that, even in the absence of state control, organized labor would remain relatively weak. For, while state interference may be partially to blame for the weakness of labor-based organizations, the source of dysfunction is as much developmental as it is political. Students of civil society have long recognized that the structure of associational life is determined in part by the structure of the economy. Marx's and Engels' (2012 (1848), 78) arguments about the "idiocy of rural life" aside, in the absence of industrialization and the attendant politics of the shop floor, class-based collective action is subordinated to traditional forms of social organization. Thus, it is unsurprising that leftist parties would find it difficult to reach voters in a country such as Egypt, even as those voters would likely find the policies offered by leftist parties congenial to their own shrewd sense of where their economic interests lie.

\section{Empirical Analyses}

This article has argued that Islamists outperform leftist parties in part because Islamist activists are embedded in religious social networks that enable them to reach large numbers of voters. In contrast, the labor-based organizations that could 
Fig. 9: Religious versus non-religious associations in Egypt

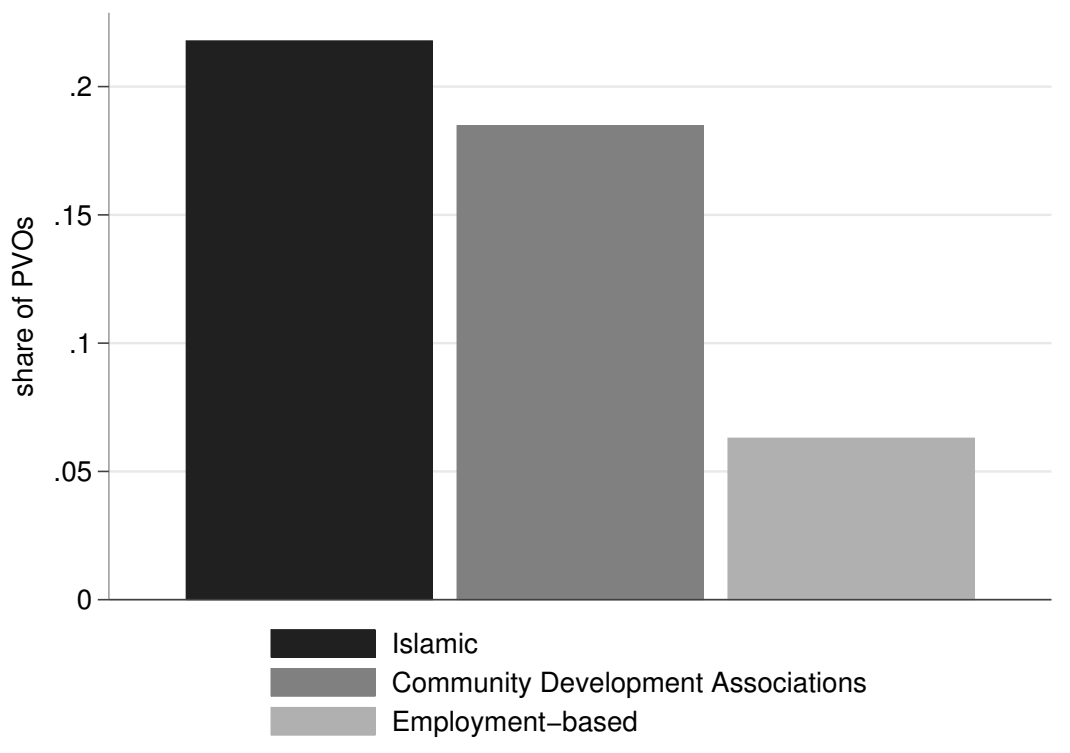

offer leftists analogous linkage opportunities are weak-a product both of a long legacy of state control and a workforce that is largely agrarian and informal. Consequently, while Islamists have many channels through which to communicate with voters, leftists have relatively few-a fact reflected most poignantly in voter ignorance and misapprehension of leftist economic policy stances. In this section, I test the argument with aggregate and individual-level data from recent Egyptian elections.

\subsection{Religious institutions and Islamist voting in Cairo and Alexandria neighborhoods}

One of the observable implications of the argument advanced here is that Islamist vote shares should be positively correlated with the density of Islamic institutions. There are obviously potential confounds that would have to be controlled formost notably, both Islamist vote shares and the density of religious institutions could be functions of some deeper variable, such as popular religiosity. But as a first cut at assessing the plausibility of the argument, I examine the correlation between voting for Islamists and the distribution of religious institutionsspecifically, mosques - in Egypt's two largest cities, Greater Cairo and Alexandria, after the Arab Spring.

Though we are interested in exploring the effect of Islamic institutions on voting for Islamists, spatial data on such institutions is limited. Therefore, we focus primarily on the relationship between mosques (for which spatial data is available) and Islamist voting. ${ }^{73}$ Mosque coordinates were collected from the Google

\footnotetext{
${ }^{73}$ Based on my admittedly unsystematic observations, there is a high co-incidence between
} 
Places database, in which houses of worship were queried at every 0.0025 degree of latitude (to obtain the nearest 20 houses of worship every 750 feet). Though the Google Places database-which draws on Egyptian government sources and directories - is reasonably comprehensive, it is not exhaustive. For example, coverage is thin outside of Cairo and Alexandria, forcing us to restrict our analyses to neighborhoods in those two cities. ${ }^{74}$ Another cause for caution is the fact that, even within Cairo and Alexandria, the database's mosque coverage is incomplete. According to the ministry of religious endowments, the number of large mosques in those two cities is 4,772, and the total zawāyā are 9,203. However, the total number of mosques obtained from the Google database is 6,594, and a spot check of the locations of those mosques leads us to conclude that the database captures most large mosques, but severely undercounts zawāy $\bar{a}$. Figure 10 displays the spatial distribution of mosque density (calculated as the number of mosques per 10,000 inhabitants).

Our principal dependent variable is the share of votes cast for Islamist parties and candidates. Here, too, we run into data limitations. Though ideally we should analyze the results of Egypt's first post-authoritarian parliamentary elections, returns for that contest are not available at the neighborhood level, but instead are reported only at the level of the electoral district. As described earlier, the electoral system employed during the parliamentary contests was comprised of two tiersa list tier of 46 multi-member districts, and a constituency tier of 83 dual member districts. Together, Cairo and Alexandria were allocated 6 districts in the list tier, and 13 in the constituency tier-neither offering a large enough sample for econometric analysis. Consequently, the analysis in this section is restricted to elections for which it was possible to obtain data at a lower level of aggregation (in this case, the second-degree administrative unit, or qism, of which Greater Cairo and Alexandria together make up more than 60). There are three elections for which qism-level data were available. These were:

- The March 19, 2011 constitutional referendum. That referendum asked Egyptians to vote on a package of 9 amendments to the country's 1971 constitution, which had been suspended after Mubarak's departure. The amendments were written by a committee of legal experts, chaired by the Islamistleaning jurist Tāariq al-Bishrī, and were endorsed by the Muslim Brotherhood and the major Salafi associations. Three days before the referendum, the JS took out an advertisement in Egypt's largest newspaper, al-Ahram, declaring that it was "a religious duty for every Egyptian to take care to vote in favor of the amendments."75 Therefore, I use the percentage of "yes" votes

mosque presence and the presence of Islamic charitable associations. Moreover, since 2002, the ministry of religious endowments has stipulated that all newly-built mosques must dedicate space for social services, thus ensuring further spatial convergence between these two types of Islamic institutions over time.

${ }^{74}$ The dataset includes 20 aqsam from the governorate of al-Giza, which are considered part of Greater Cairo.

75 “Bayan al-Jam'iyya al-Shar'iyya al-Ra'isiyya bi-sha'n al-istifta' 'ala al-ta'dilat al-dusturiyya 
Fig. 10: Mosque density in Cairo and Alexandria
(a) Cairo
(b) Alexandria
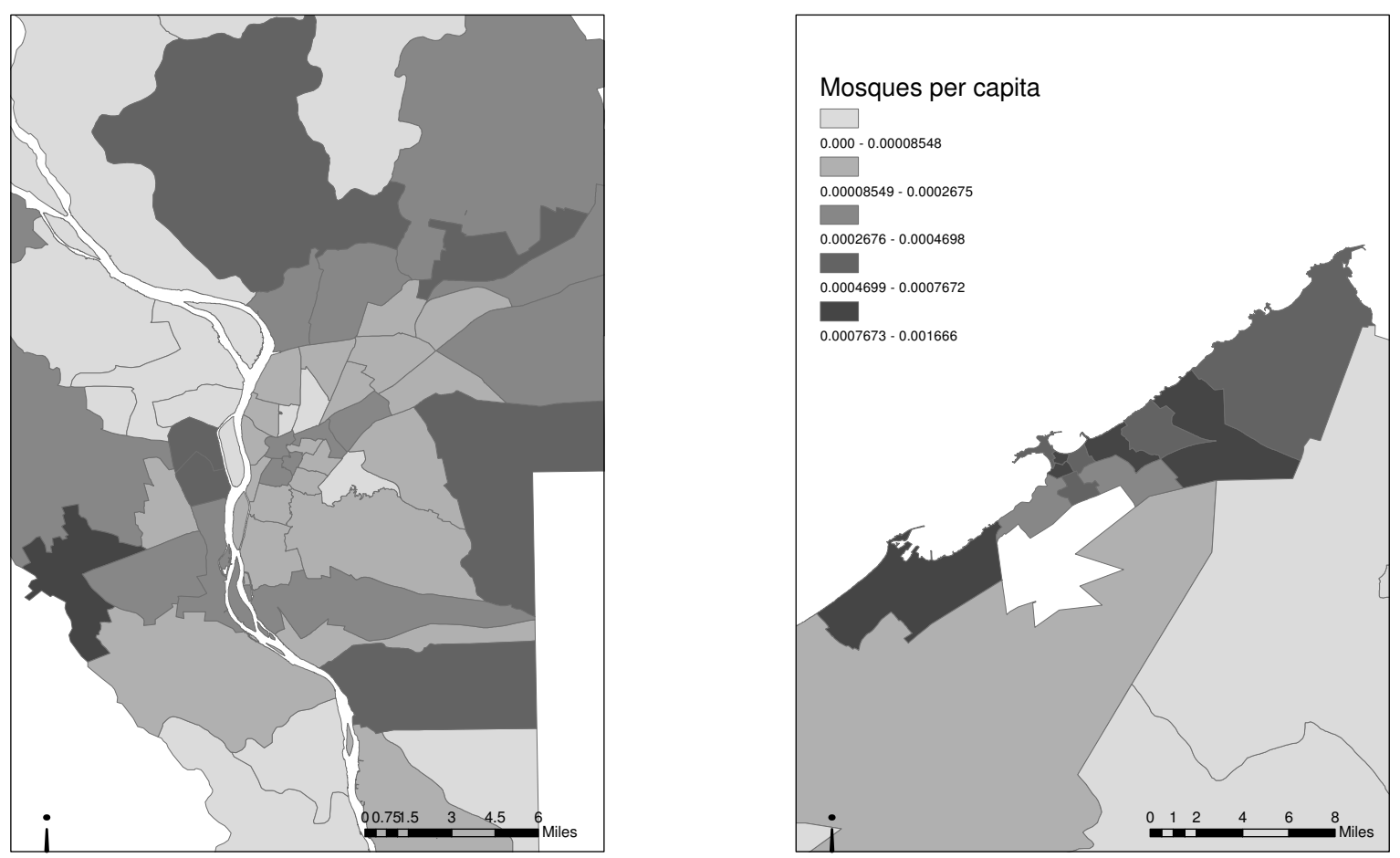
to proxy for Islamist support, recognizing that it is at best an imperfect proxy (Masoud 2011, 30).

- The first round of the most recent presidential election, conducted on May 23 and 24, 2012. In that contest, each of the country's two major Islamist parties-the FJP and the Nūr Party-supported a different candidate. The FJP supported its party leader and member of the Brotherhood's executive committee, Mohamed Morsi, and the Nūr Party supported 'Abd al-Mun'im Abū al-Futūh, a former member of the Brotherhood who departed the movement shortly after the Egyptian revolution. Though Abū al-Futūh was widely considered more liberal than his Salafi supporters (and than his Brotherhood rival), 74 of the Nūr party's 123 members of parliament voted to support him for president, as did 8 of the 11 members of the party's high committee. ${ }^{76}$ According to the Nūr party's secretary, 'Imad 'Abd al-Ghafur, the party supported Abu al-Futuh in order to prevent the Muslim Brotherhood from monopolizing power. ${ }^{77}$

- The second round of the presidential election, held on June 16 and 17, 2012. The Egyptian electoral law requires a runoff between the top two vote-getters if no candidate earns more than $50 \%$ of the vote. The FJP's Morsi faced Ahmad Shafiq, a former air force general who had held the posts of minister of civil aviation and prime minister under Mubarak.

I estimate a regression of the form:

$$
\text { IslamistVote }_{i}=\beta_{0}+\beta_{1} \text { MosqueDensity }_{i}+\beta^{\prime} X+\varepsilon_{i}
$$

Where IslamistVote is the vote share captured by Islamists in qism $i$, and MosqueDensity is a measure of the number of mosques in the qism per 10,000 people. $X$ is a vector of covariates including the percentage of workforce in agriculture (in order to capture the extent of urbanization), the unemployment rate, the average number of inhabitants per household room (to proxy for socioeconomic status), and the logged qism population. All demographic variables are drawn from the 2006 population census conducted by the Egyptian Central Agency for Public Mobilization and Statistics (al-Jihāz al-Markazī lil-Ta'bi'a al-'Āmma wa al-Ihșā'). ${ }^{78}$

I run four models, each with a different proxy for the dependent variablemodel 1 employs as its dependent variable the percentage "yes" votes in the March

(Statement of al-Jam'iyya al-Shar'iyya Headquarters in the matter of the referendum on the constitutional amendments)," advertisement on page 1 of al-Ahram (Cairo), March 19, 2011

${ }^{76}$ Bāhī Hasan, "Ḥizb al-Nur ya'lan rasmiyan da'm al-Futuh li-ri'asat al-jumhuriya (The Nūr Party officially announces its support for al-Futuh for president of the republic)," al-Misri al-Yawm (Cairo), April 28, 2012

77 See: "'Abd al-Ghafur: Hizb al-nur qad yad'am Abu al-Futuh li-ri'asat Misr ('Abd al-Ghafur: The Nūr party may support Abu al-Futuh for the presidency)," al-Misri al-Yawm (Cairo), April 25, 2012; and "Egypt Salafis back Abol Fotouh for president," al-Jazeera, April 29, 2012 (available at: http:/ /www.aljazeera.com/news/middleeast/2012/04/2012428234136158208.html).

${ }^{78}$ Qism and markaz level 2006 census data are available here: http:/ / www.censusinfo.capmas.gov.eg 
Tab. 1: Summary statistics, Cairo and Alexandria aqsam

\begin{tabular}{lccccc}
\hline Variable & $N$ & $\mu$ & $\sigma$ & $X_{\min }$ & $X_{\max }$ \\
\hline \hline \% Yes, March 2011 referendum & 65 & 66.45313 & 15.61887 & 31.81979 & 96.66718 \\
\% Voting Abū al-Futūh, May 2012 & 65 & 17.45343 & 6.04029 & 7.563471 & 39.75454 \\
\% Voting Morsi, May 2012 & 65 & 18.303 & 9.206028 & 5.261542 & 49.01502 \\
\% Voting Morsi, June 2012 & 64 & 46.71733 & 13.23682 & 21.43329 & 77.4473 \\
Mosques per 10K & 65 & 3.813501 & 3.985515 & 0 & 16.65809 \\
\% Workforce in agriculture & 64 & 1.816467 & 4.546526 & 0.0143012 & 25.65077 \\
\% Unemployed & 63 & 61.27007 & 3.28191 & 53.71615 & 70.75632 \\
Log population & 65 & 11.9869 & 1.049632 & 8.962904 & 13.97182 \\
Crowding rate & 65 & 1.09832 & 0.1434814 & 0.5762787 & 1.512419 \\
\hline
\end{tabular}

2011 referendum; models 2 and 3 use vote shares in the first round of the presidential election for Morsi and Abū al-Futūh respectively; and model 4 uses vote shares for Morsi in the presidential election's runoff. Summary statistics for the key variables are available in table 1 . The results of all four regressions are reported in table 2, and figure 11 contains marginal effects plots of increasing mosque density on the predicted (a) "yes" vote, vote shares for (b) Morsi and (c) Abū al-Futūh in the presidential election's first round, and vote share for (d) Morsi in the runoff.

As is apparent from table 2 and the marginal effects plots, the effect of mosque density is positive and statistically significant only in two of the four modelsvote share for $A b \bar{u}$ al-Futūh in the first round of the presidential election, and vote share for Morsi in the runoff. The relationship is positive, but not significant, when the dependent variable is the share of referendum "yes" votes, perhaps reflecting the fact that the $77 \%$ of voters who approved them were responding not only to Islamist appeals, but also appeals of the former ruling party (which had not yet been dissolved), as well as appeals of the country's military rulers, who were then basking in the glow of public acclaim for safeguarding the revolution. The insignificant, and negative, coefficient on Morsi's first round vote share, and the positive and significant coefficient on Abu al-Futūh's, may reflect differences in the ability of the Muslim Brotherhood and the Salafi Da'wa to use mosques to get out the vote for their candidates. Though both the Brothers and the Salafis employed mosques for linkage, the Salafis may have had superior ability to do so, based on the fact that their quiescence during the Mubarak regime meant they were traditionally allowed more room to maneuver in mosques. The fact that mosque density is a positive and significant predictor of Morsi's second round vote share may reflect the rallying of all Islamists behind him as the only Islamist candidate.

However, as noted earlier, aggregate data of this nature can only be suggestive. In addition to the fact that we are unable to control for potential confounds-most notably, the baseline level of religiosity in a given qism-we are also confronted with the problem of inferring individual behavior of aggregate data (King 1997). But, most importantly, though correlations between the presence of Islamic institutions and support for Islamist parties are generally consonant with the argu- 
Fig. 11: Marginal effects of mosque density on Islamist voting in Egypt

(a) \% "yes," March 19, 2011 referendum

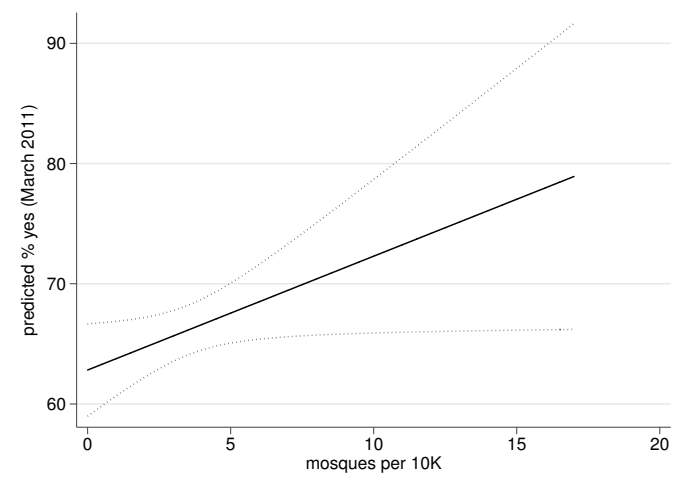

(c) Vote \% for Abū al-Futūh, May 13-14, 2012

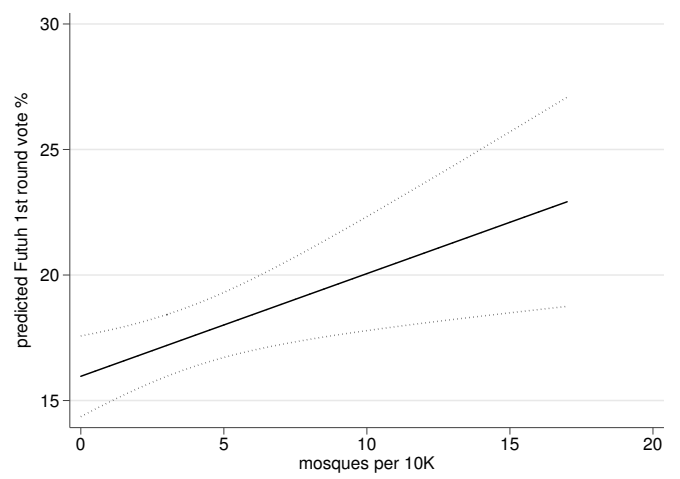

(b) Vote \% for Morsi, May 13-14, 2012

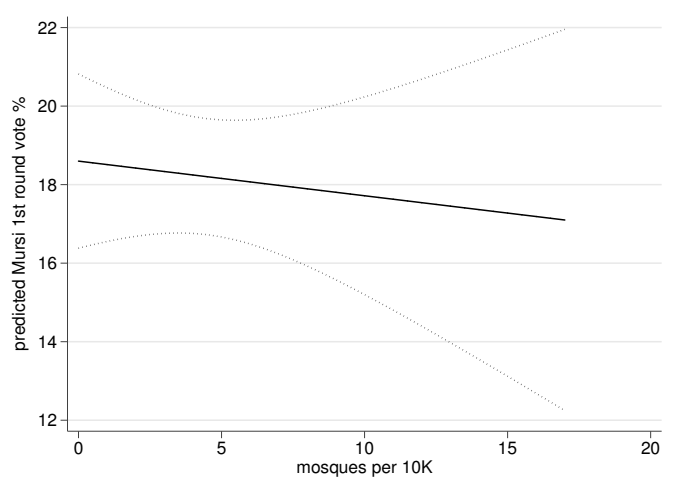

(d) Vote \% for Morsi, June 16-17, 2012

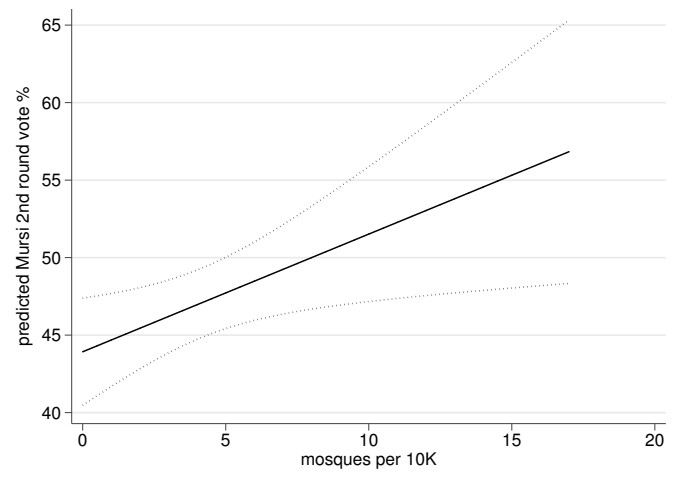


Tab. 2: OLS regressions of correlates of pro-Islamist voting over three elections, Cairo \& Alexandria

\begin{tabular}{lcccc}
\hline & $\begin{array}{c}\text { \% Yes } \\
(3 / 19 / 11)\end{array}$ & $\begin{array}{c}\text { \% Morsi } \\
(\text { Round 1) }\end{array}$ & $\begin{array}{c}\text { \% Futuh } \\
\text { (Round 1) }\end{array}$ & $\begin{array}{c}\text { \% Morsi } \\
\text { (Runoff) }\end{array}$ \\
\hline \hline Mosques per 10K & 0.571 & -0.196 & $0.347^{* *}$ & $0.707^{* *}$ \\
\% Workforce in agriculture & -0.456 & $(0.181)$ & $(0.131)$ & -0.277 \\
& $1.578^{* * *}$ & $1.008^{* * *}$ & $0.810^{* *}$ & $1.650^{* * *}$ \\
\% Unemployed & $(0.356)$ & $(0.377)$ & $(0.315)$ & $(0.601)$ \\
& 0.126 & -0.00194 & 0.0160 & 0.422 \\
Log population & $(0.469)$ & $(0.215)$ & $(0.200)$ & $(0.328)$ \\
Crowding rate & -1.161 & $1.420^{*}$ & $1.323^{*}$ & $3.304^{* * *}$ \\
& $(1.212)$ & $(0.712)$ & $(0.714)$ & $(1.153)$ \\
Constant & $77.91^{* * *}$ & $26.29^{* * *}$ & -4.808 & $26.99^{* * *}$ \\
& $(11.27)$ & $(5.539)$ & $(3.427)$ & $(8.614)$ \\
\hline Observations & -18.17 & $-28.53^{*}$ & 3.176 & $-54.08^{*}$ \\
R-squared & $(31.14)$ & $(16.74)$ & $(15.97)$ & $(27.24)$ \\
\hline Standard errors in parentheses. & *** $p<0.01,{ }^{* *} p<0.05, * p<0.1$ & 65 \\
& 65 & 63 & 63 & 0.551 \\
\hline
\end{tabular}

ment presented here, they actually do not get at the core mechanism this article attempts to explore-specifically, how Islamic institutions provide Islamist parties with greater access to voters, and how this allows them to shape voter perceptions of where those parties stand economically.

\subsection{Individual-level evidence}

As noted earlier, though the economic agenda of the Egyptian left appears highly congruent with the preferences of Egyptian voters, the latter are unaware of this fact, and instead believe Islamists-whose stances toward welfare and redistribution are complicated at best-to most share their views. The explanation offered here is that leftists have few channels through which to convince voters otherwise, whereas Islamists can make use of dense webs of mosques and religious associations in order to make their case to voters. In order to probe this argument, I analyze data gathered during a nationally-representative survey of Egyptian political attitudes and behavior, conducted in the midst of Egypt's first free parliamentary elections. If the theory outlined here is correct, we should observe that voters who are embedded in Islamic social networks-mosques, charities, and religious lessons-are more likely to believe that Islamists are welfare-statist and redistributive. Similarly, those embedded in networks of labor activism-which bring them in contact with leftist party activists-should be more likely to assign such preferences to parties of the left.

For this analysis, I use the questions described in section 2, where voters were 
asked to place parties with respect to two economic issues-redistribution and government responsibility for welfare. We want to know whether embeddedness in particular kinds of networks affects a respondent's propensity to consider a party economically "left." For this analysis, we focus on the Freedom and Justice Party, the Nur Party, and the NPUR.

I estimate three separate regressions-one for each party-in which the dependent variable is a dichotomous measure of whether the respondent placed the party on the left. In order to generate these measures, I sum the respondent's answers to the two questions for each party, and then generate a dichotomous variable set to 1 if the respondent's combined score for that party puts it on the left end of the spectrum or the right (on a scale from 2 to 20). ${ }^{79}$ For each party, I fit a logistic regression of the form:

$$
\operatorname{Pr}\left(\text { Left }_{p_{i}}=1\right)=\frac{e^{\beta_{0}+\beta^{\prime} \text { Embeddedness }_{i}+\gamma^{\prime} X}}{1+e^{\beta_{0}+\beta^{\prime} \text { Embeddedness }_{i}+\gamma^{\prime} X}}
$$

Where Left $_{p_{i}}$ is a dichotomous variable connoting whether respondent $i$ placed party $p$ on the left of the economic spectrum. Embeddedness is a vector of covariates capturing the key independent variables in this study, which are measures of a respondent's membership in religious and labor-based associations. We want to know if a respondent's embeddedness in particular forms of association influence his or her information about, and assessments of, different political parties. The embeddedness measures are:

- Frequency of mosque attendance, coded 1 if the respondent attends mosque at least once a week, and 0 otherwise. If mosques are thought to be a prime channel through which Islamist parties communicate with voters, then we should expect that voters who attend mosque more frequently to have greater access to Islamist party messages, and thus to have a greater propensity to trust or vote for those parties, controlling for political ideology.

- Reliance on Islamic charity. Respondents were asked if they have relied in the past on an Islamic charity (jam'iyya khayriyya Islämiyya) for health services. Those answering in the affirmative were coded 1, all others were assigned a score of zero. Given the embeddedness of Muslim Brothers in particular in networks of religious charity, we might expect that voters who have relied on such charities would be more likely to believe in the welfarist orientation of the Brotherhood.

- Religious and scriptural studies. Respondents were asked whether they attend religious lessons or sessions (durūs aw jalasāt dīniyya) or attend an institute for memorizing the Qur'an (maqra'a). A dichotomous variable was created, coded 1 if respondents answered yes to one or both of these questions, and 0 otherwise. We should expect participants in such lessons to be

\footnotetext{
${ }^{79}$ Respondents who failed to place a party on the economic dimension were coded as " 0 "- -i.e. as not placing that party on the left.
} 
more likely to place Islamist politicians and parties on the redistributive and welfare-statist end of the spectrum.

- Union membership. Respondents were asked whether they were enrolled in a labor union. Those who answered affirmatively were coded 1, all others received a score of 0 . If leftist parties and political activists are embedded in labor unions, we should find that citizens who are similarly situated should actually be able to place leftist parties on the left end of the economic spectrum. The total share of respondents in the sample who admit to being union members is $6.5 \%$ of the sample and $10.5 \%$ of those indicating that they are employed.

In addition to measures of embeddedness, I include a vector of covariates $X_{i}$ to control for potential confounding influences on a respondent's placement of political parties. These include education, unemployment, urbanization, gender, and age. ${ }^{80}$ The results of the three regressions are presented in table 3.

In column 1, the dependent variable is the respondent's placement of the Muslim Brotherhood's Freedom and Justice Party. Mosque attendance does not seem to influence individuals' judgments of the FJP's economic stance. However, recipients of Islamic charity did appear to be more likely to place the FJP on the left than non-recipients. This may be due to the fact that Islamic charitable activities provide the Brotherhood with both access to voters and a demonstration of its commitment to social welfare. What this suggests is that the clientelistic mechanism so often posited to explain support for Islamism may also act by making voters think that the movement will use the apparatus of the state to ameliorate poverty and inequality. ${ }^{81}$ There is also a positive and significant relationship between a respondent's attendance at religious lessons or Qur'anic sessions and the likelihood of placing the FJP on the left. In order to quantify the magnitude of the effects of Islamic charity and participation in religious lessons, I employ King, Tomz, and Wittenberg's (2000) Monte Carlo simulation routines to estimate the increase in the probability that a respondent will place the Brotherhood's political party on the left conditional upon changes in these two variables (holding all other variables constant at their means). ${ }^{82}$

The results of the simulations are presented graphically in figure 12 . Figure $12 \mathrm{a}$ contains two smoothed histograms of the simulated probabilities that a respondent will place the Muslim Brotherhood on the left. The dotted line represents the

\footnotetext{
${ }^{80}$ Non-muslims (who make up 109 of the 1,675 respondents) were dropped from the analysis, as there is almost perfect collinearity with Islamic embeddedness variables. When non-Muslims are excluded, diagnostics for collinearity reveal low variance inflation factors on all variables $(<2.05)$ and a condition number of 12.34, indicating that collinearity is not a serious concern. See discussion in Snee and Marquardt (1984).

${ }^{81}$ Caution is in order here, however. A version of this analysis in which measures of economic policy were not aggregated but analyzed separately revealed no statistically significant relationship between Islamic charity receipt and left placement of the FJP.

82 The quantity of interest is given by the equation:

$$
\triangle \operatorname{Pr}\left(F J P_{\text {left }}=1\right) \mid \triangle X=\frac{\operatorname{Pr}\left(F J P_{\text {left }}=1 \mid X_{1}\right)-\operatorname{Pr}\left(F J P_{\text {left }}=1 \mid X_{0}\right)}{\operatorname{Pr}\left(F J P_{\text {left }}=1 \mid X_{0}\right)} \times 100
$$
}


Tab. 3: Logit analyses of party economic placement

\begin{tabular}{lccc}
\hline & FJP & Nūr & NPUR \\
\hline \hline Prays in mosque $\geq$ once weekly & 0.0624 & 0.194 & 0.182 \\
Recipient of Islamic charitable services & $(0.141)$ & $(0.141)$ & $(0.162)$ \\
& $0.533^{* * *}$ & 0.258 & 0.216 \\
Religious lessons & $(0.187)$ & $(0.182)$ & $(0.206)$ \\
& $0.419^{* *}$ & $0.432^{* *}$ & -0.0257 \\
Union member & $(0.203)$ & $(0.200)$ & $(0.242)$ \\
& 0.00901 & $0.453^{*}$ & $0.567^{* *}$ \\
education & $(0.247)$ & $(0.240)$ & $(0.259)$ \\
& $0.139^{* * *}$ & $0.109^{* * *}$ & 0.0628 \\
unemployed & $(0.0400)$ & $(0.0407)$ & $(0.0481)$ \\
& -0.0457 & -0.00294 & 0.206 \\
urban & $(0.147)$ & $(0.148)$ & $(0.174)$ \\
female & -0.0357 & 0.00617 & -0.206 \\
& $(0.118)$ & $(0.118)$ & $(0.137)$ \\
age & $-0.398^{* *}$ & -0.251 & -0.260 \\
& $(0.163)$ & $(0.165)$ & $(0.193)$ \\
Constant & $-0.00792^{*}$ & $-0.00700^{*}$ & -0.000645 \\
& $(0.00413)$ & $(0.00415)$ & $(0.00494)$ \\
$\mathrm{N}$ & 0.0525 & -0.393 & $-1.413^{* * *}$ \\
\hline
\end{tabular}

Standard errors in parentheses. ${ }^{* * *} p<0.01,{ }^{* *} p<0.05,{ }^{*} p<0.1$ 
distribution of simulated probabilities when Islamic charity is constrained to 0 (i.e. no Islamic charitable aid is received), and the solid line is the distribution of simulated probabilities when Islamic charity is set to 1 . On average, an individual was found to be between $17.5 \%$ and $36 \%$ more likely to place on the FJP on the left end of the spectrum if he benefitted from Islamic charitable services than if he had not. Figure $12 \mathrm{~b}$ displays the change in probability of placing the FJP on the left conditional on a change in attendance at religious lessons. On average, a respondent was between $10.5 \%$ and $30.7 \%$ more likely to place the FJP on the left if he attended religious lessons than if he hadn't.

Column 2 of table 3 displays the results of the same analysis for the Salafist Nūr Party. As with the FJP, the coefficient on mosque attendance is insignificant. However, unlike the FJP, reliance on Islamic charity was also insignificant, perhaps indicating the Salafi movement's focus on religious preaching and proselytizing rather than on serving the poor. Consistent with this, we find that coefficient on participation in religious instruction is positive and significant. The effect of this variable on respondents' propensity to judge the Nūr party leftist is represented graphically in figure 13. On average, an attendee at religious lessons and Qur'anic sessions was found to be between $13 \%$ and $39 \%$ more likely than a non-attendee to place the Nūr Party on the left.

Though the coefficient on union membership is not a significant predictor of perceptions of either the Muslim Brotherhood, it is-as expected-a positive and significant predictor of a respondent's propensity to identify the NPUR as a leftist party (column 3, table 3). On average, a union member was between $27 \%$ and $78 \%$ more likely to place the NPUR on the left than was a non-union member (a fact represented graphically in figure 14).

More work is needed to tease out the causal mechanisms by which voters arrive at assessments of the economic policy stances of political parties, but the evidence gathered in this section suggests that an important part of the story are the associations and organizations in which voters are embedded. Citizens embedded in Islamic networks were more likely to conclude that Islamic parties were welfarestatist and redistributive, whereas those who were members of labor unions had more progressive assessments of the left. Given that there are many more Egyptian citizens in the former category than the latter, it should not be surprising that citizens think Islamists are more economically progressive than their leftist counterparts, and vote accordingly.

\section{Prospects for pluralism}

In this article, I have shown that Egyptian voters value robust welfare states and redistribution, believe that Islamists want these things too, and think leftists want the opposite. I have argued that the reason for this strange misperception regarding parties of the left lies neither in the stupidity of voters nor the strategic and organizational deficiencies of leftist parties, but rather in a social landscape that simply makes it harder for leftists to communicate with potential constituents. 
Fig. 12: Simulated effect of key Islamic social variables on probability of identifying the Freedom and Justice Party as welfare-statist.

(a) Islamic charity

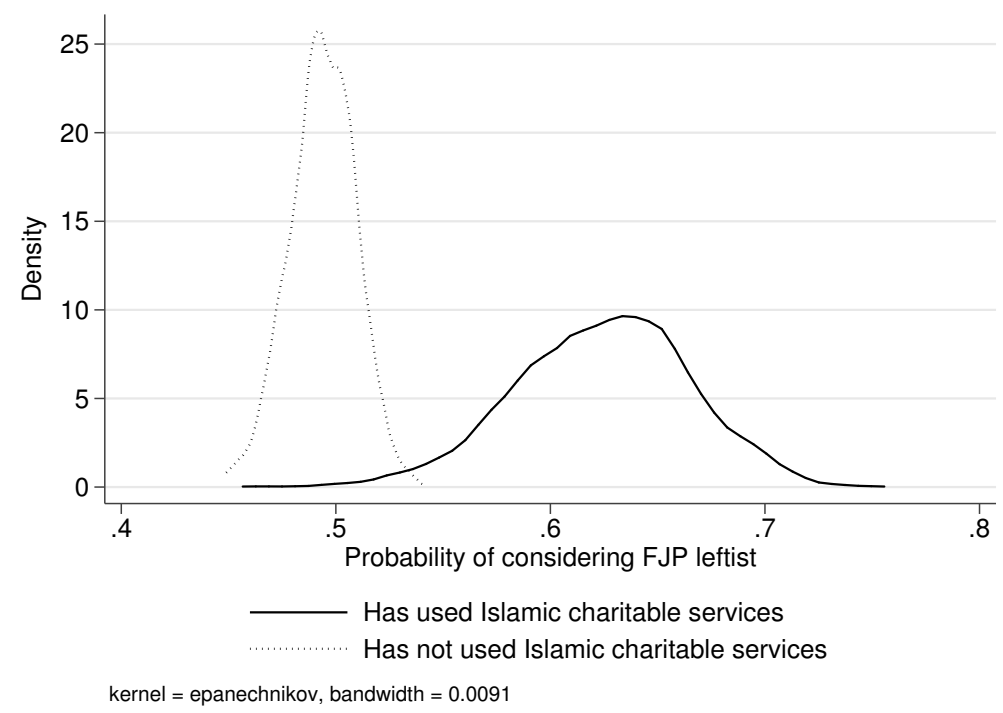

(b) Religious lessons

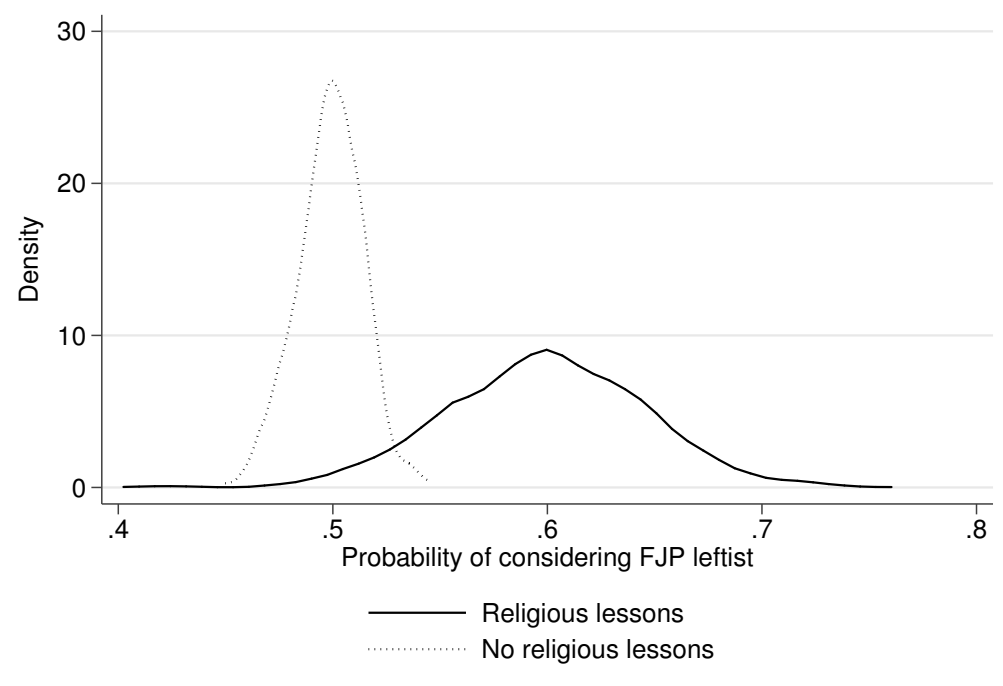

kernel $=$ epanechnikov, bandwidth $=0.0104$ 
Fig. 13: Simulated effect of religious lesson attendance on placement of Nur party on left

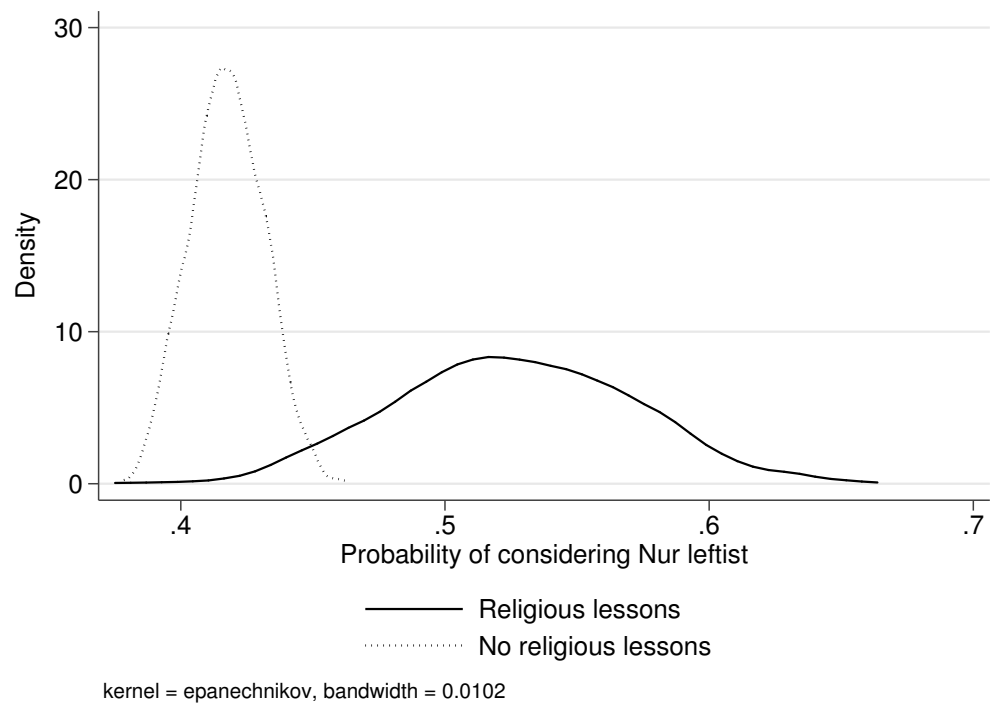

Fig. 14: Simulated effect of union membership on probability of identifying NPUR as redistributive.

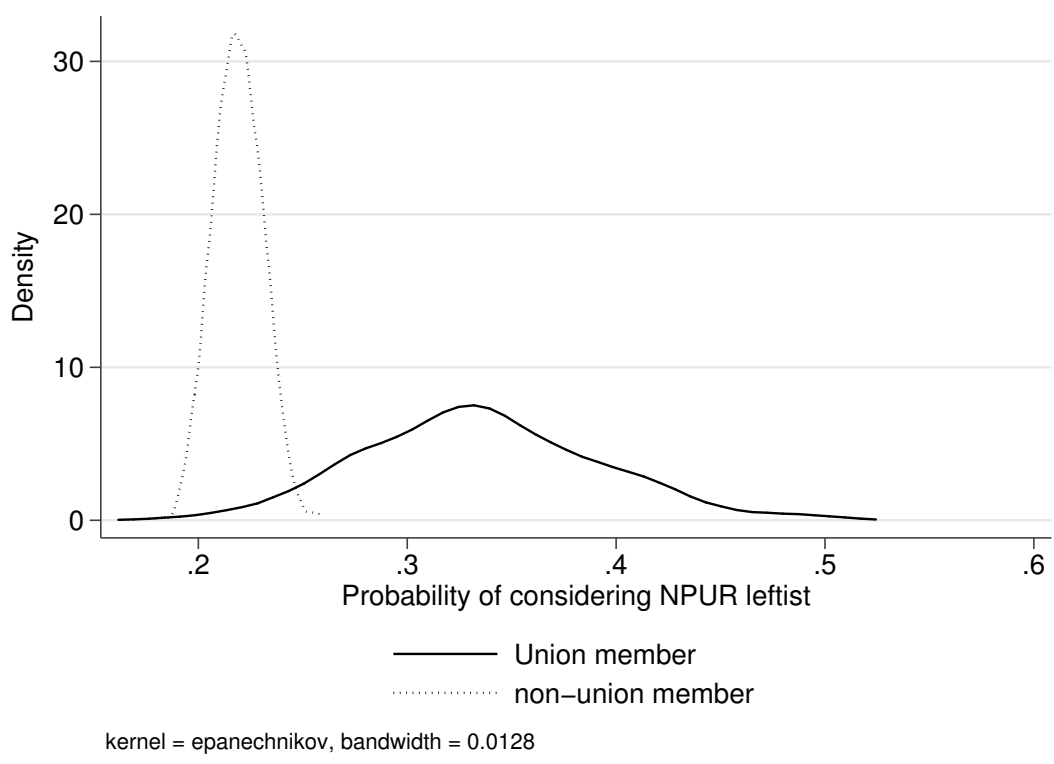


Legacies of authoritarian control, coupled with the realities of economic underdevelopment, mean that leftist opportunities for linkage-through labor unions and other manifestations of modern civil society-are simply much scarcer than the opportunities enjoyed by Islamists, who revel in a rich landscape of religious institutions with which they have countless affinities and which provide them extensive access to voters. Thus, while leftist parties produce redistributive platforms, Islamists instead are actually able to generate the kinds of interactions that can convince voters that they share their economic values (even if Islamists' formal party platforms are more ambiguous on this score). The argument shares much with that of Tsai (2007), who shows that elites who are embedded in religious solidary organizations are more receptive to their communities. Here I have explored a complementary phenomenon-that common embeddedness in solidary groups makes communities more receptive to political elites.

Those concerned with boosting the fortunes of leftist parties (and non-Islamists in general) might reach one of two, largely opposing, conclusions from this analysis. The first is that the answer for parties of the left is to don religious garb and get themselves to the nearest mosque. But what I've tried to suggest is that it's not that simple. Embeddedness takes time, and Islamists have a longstanding and largely organic advantage. The second conclusion is that the situation is largely hopeless. If Islamists possess an informational and communication advantage that is conferred on them by nothing less than the structure of civil society, what hope do secular parties have? At best, the argument presented here might suggest that the most promising potential source of competition with parties like the FJP and the Nūr would come from within those parties, as economically-progressive Islamists peel away from their more conservative brethren. Though this would be pluralism of a sort, it is certainly a far more constrained form than was hoped for during those heady opening days of 2011.

There are, however, reasons to believe that the advantage that Islamists have over their secular rivals is a bounded one. The economic challenges that inspired the revolution against Mubarak-high unemployment and a retrenchment of state commitments to social welfare-continue to bedevil the country. Long called-for economic reforms - such as trimming the bloated public sector and inefficient food and fuel subsidies-threaten to inflame public sentiment against Morsi and the Muslim Brotherhood. As Morsi comes under increasing pressure to reform from donors and lenders, it is likely that the benefit of the doubt accorded to the Muslim Brotherhood by Egypt's voters will wear thin. Egyptians may have believed, at $t=0$, that the Brotherhood wanted a robust welfare state and greater redistribution, but it will be increasingly difficult for them to maintain that fiction as time wears on.

There is evidence that a nationwide process of Bayesian updating regarding the Brotherhood has already begun. For though the last two years have appeared to be one long Islamist victory streak, those victories have been increasingly narrow ones. Islamists captured a majority of the vote in the 2011 parliamentary election, but they fared far less well in the 2012 presidential elections. And though that latter contest eventually brought a Muslim Brother to power, it was only on the thinnest 
Tab. 4: Candidate vote shares in first round of 2012 presidential election

\begin{tabular}{llcc} 
Name & Party & votes & $\%$ \\
\hline \hline Mohamed Morsi & Freedom and Justice & $5,764,952$ & $25 \%$ \\
Ahmad Shafiq & None (former NDP) & $5,505,327$ & $24 \%$ \\
Hamdin Sabahi & al-Karama & $4,820,273$ & $21 \%$ \\
'Abd al-Mun'im Abu al-Futuh & Independent (Nūr party) & $4,065,239$ & $17.5 \%$ \\
'Amr Musa & None & $2,588,850$ & $11 \%$ \\
\hline
\end{tabular}

of margins, and against a figure widely reviled as a pillar of the regime Egyptians had overthrown a mere 17 months earlier. In fact, as many Egyptian commentators have noted, if one examines the first round of the presidential election result (see table 4), Islamists captured at best $43 \%$ of the vote, leaving the lion's share to a fragmented non-Islamist field.

One lesson that many have taken from the result of that election is that secularists need to put aside their differences and unite in order to defeat the Islamist juggernaut. However, the results are more instructive for what they say about emergent sources of pluralism and competition in the new Egypt. For while it is perhaps unremarkable that the top two candidates in Egypt's first real presidential election were a Muslim Brother and a member of the old regime, the genuine surprise to many observers of the Egyptian political landscape was the third place finish of Hamdīn Șabāḥ̄, a journalist and head of the small, Arab nationalist, Karāma Party (which in the 2011 parliamentary election had joined the Muslim Brotherhood's slate and earned 6 seats in the bargain). Șabāḥ̄ positioned himself as a believer in the Nasserist project of restoring Egypt's leadership of the Arab world and reestablishing the social contract at home. His campaign slogan-wāhid minina (he's one of us) -attests to his populism. ${ }^{83}$ His official campaign biography makes no bones about his commitment to workers and the poor. Where Mohamed Morsi's campaign flyers emphasized his technical credentials-a doctorate from the University of Southern California and an alleged stint working on space shuttle engines for the National Aeronautics and Space Administration-Sabāhī's biography speaks of his participation in protests (led, incidentally, by the NPUR) against an unpopular 1990s land reform law that eliminated Nasser-era protections for tenant farmers (Kienle 2001, 92). ${ }^{84}$ We read that Ṣabāḥ̄ was subject "to a string

\footnotetext{
${ }^{83}$ Muhammad al-Khuli, "Hamdīn Șabāhīi: Murashah al-'ummal wa al-falahin wa al-talaba (Hamdīn Șabāhīi: Candidate of workers, farmers, and students)," al-Akhbar (Cairo), May 22, 2012

84 The Muslim Brotherhood's position on the reforms was one of muted assent. As one Muslim Brotherhood supporter put it to a Western journalist at the time, "Islam protects property rights [...] therefore the law is good." See Deborah Horan, "Egypt: State fails to tar Muslim Brotherhood with 'terrorism' brush," Inter Press Service, October 24, 1997. Tingay $(2006,22)$ calls the Brotherhood an "oustpoken supporter" of the law, and one socialist writer noted at the time that, although the Brotherhood was "timid" in its show of support for the law, it nonetheless "stood clearly on the side of large landowners and capitalists." See Rafiq Zahran, "al-Haraka al-falahiyya wa qanun tard al-musta'jirin (the peasants movement and the law of expulsion of tenants," al-Sharara, September 1997. Available at: http://www.e-socialists.net/node/5502
} 
of arrests, among them when he led demonstrations in 1997 with the farmers of Egypt, who had been harmed by the land tenancy law, a law that expelled millions of poor farmers from their land, in a brazen return to the feudal system." 85

But if it was simply Șabāhî̀'s message that brought him within three percentage points of the Muslim Brotherhood, then there would be no need for this article. After all, as we have seen, other parties espoused similar messages during earlier elections, and yet only Sabāhī was able to come close to beating the storied Brothers. Adjudicating among all of the potential explanations is beyond the scope of this article. For example, it may be that Egyptian voters had decided to punish the Brotherhood for its poor performance in parliament. But, if the argument outlined here is correct, then part of the explanation for Șabāhī's rise must reside in some ability overcome the enormous informational advantage that the Muslim Brotherhood and its Islamist counterparts enjoyed by virtue of their embeddedness in religious institutions.

Given that Șabāhī's political party was small, and he a relatively impecunious journalist, it was unlikely that he suddenly found the material resources necessary to build a party apparatus that would allow him to match the Islamists' reach. And given that there were only six months between the Islamists' triumph in the parliamentary elections and their more modest performance in the presidential one, it is also unlikely that the associational landscape changed sufficiently to diminish the density of mosques or increase the density of secular organizations. Instead, it is likely that the costs of reaching out to voters during the presidential election was simply lower than it had been during the parliamentary election. After all, in a parliamentary election, candidates must make their case to voters on a district by district basis. Presidential elections on the other hand, are national in scope, and the media levels the informational playing field by beaming each candidate into living rooms and coffee shops throughout the country. As a result, voters are able to learn as much about the leader of a small party as they know about the leader of an 85-year old Islamic movement.

A second potential determinant of Sabāhị̂'s impressive vote share, and yet another potential source of political pluralism, can be observed when we disaggregate Șabāhī's vote share. Figure 15 is a scatterplot of votes for Șabāhī at the qismlevel plotted against the adult illiteracy rate (a generally reliable proxy for lack of urbanization). Though the relationship appears to be somewhat negative, we observe a set of outliers where Șabāhī's vote share exceeded 50\% (a threshold represented by the dashed line) even at high rates of illiteracy. These places turn out to be located in Șabāhī's home governorate of Kafr al-Shaykh. Did these places vote for Șabāhī because he was the hometown candidate, or because they had superior information-due to his local connections-as to his commitment to farmers? The data do not allow us to answer this question. But they do suggest that, formidable as the Islamist advantage is, it is not insurmountable.

Finally, though pluralism in Egypt and the fortunes of political Islam are im-

\footnotetext{
${ }^{85}$ Al-Birnamij al-Intikhabi lil-Murashah Hamdīn Șabāḥ̄ (Electoral Program of the Candidate Hamdīn Sabahi), 2012.
} 
Fig. 15: Qism-level vote share for Hamdīn Șabāḥ̄, March 13-14, 2012

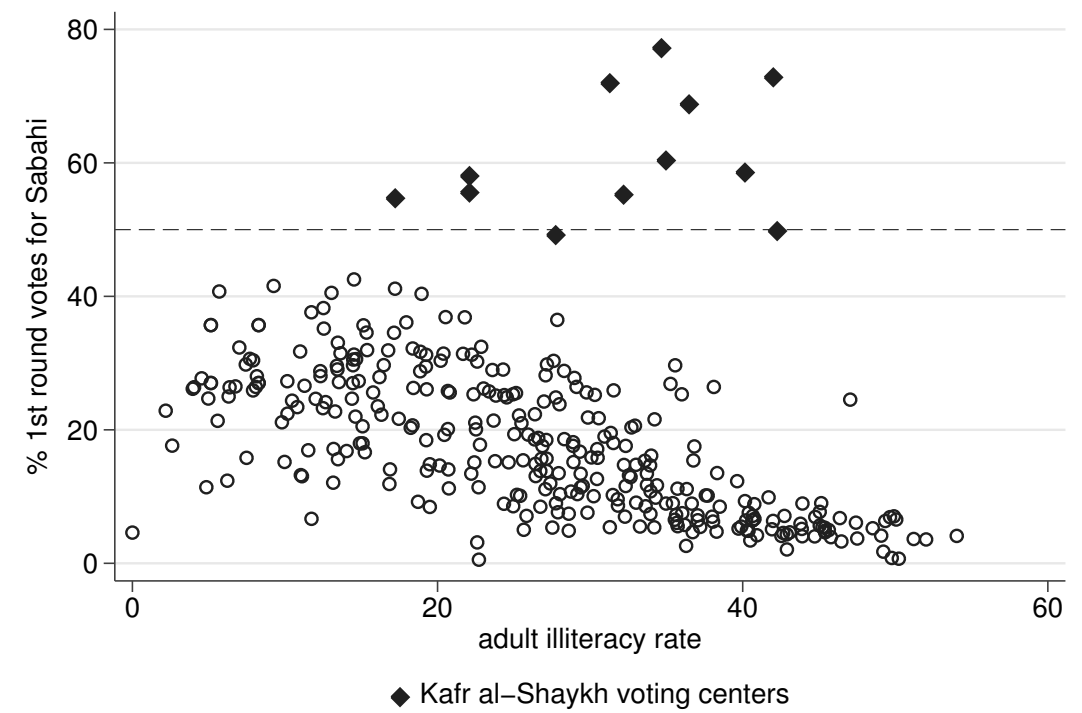

portant topics in their own rights, the analysis here raises broader questions about the likelihood for the emergence of economically progressive, pro-poor parties in the developing world. What hope is there for the left, if it is doomed to be confined to a country's narrow urban and industrial centers? Are a progressive politics in such lands always doomed to failure, unless yoked to either a religious agenda, or to the charisma (and in some cases, money) of populist political entrepreneurs? These are questions that will inspire, and haunt, future research.

\section{Bibliography}

Abed-Kotob, Sana. 1995. "The accommodationists speak: Goals and strategies of the Muslim Brotherhood of Egypt." International Journal of Middle East Studies 27(3):321.

al Azm, Sadik J. 1997. Is Islam Secularizable? In Civil Society, Democracy, and the Muslim World, ed. Elisabeth Ozdalga and Sune Persson. Swedish Research Institute in Istanbul Curzon Press.

al Majid, Wahid 'Abd and Nivin 'Abd al Mun'im Mus'ad, eds. 1992. Intikhabat Majlis al-Sha'ab 1990: Dirasa wa Tahlil (The 1990 People's Assembly Elections: Study and Analysis). Cairo University Center for Political Research and Studies.

al Munufi, Kamal. 1980. Al-Thaqafa al-Siyasiya li al-Falahin al-Misriyin: Tahlil Nazari wa Dirasa Midaniyya Fi Qarya Misriyya (The Political Culture of Egyptian Peasants: A Theoretical Analysis and Field Study in an Egyptian Village). Beirut: Dar Ibn Khaldun. 
al-Sayyid 'Abd al Wahhab, Ayman. 2011. "Al-Mujtama' al-madani al-Misri wa alintikhabat: Ishkaliyat al-dur (Egyptian Civil Society and elections: The problems of role)." Ahwal Misriyya (Egyptian Affairs) July.

Al-Sayyid, M.K. 1993. "A Civil Society in Egypt?" The Middle East Journal pp. 228242.

al Tilmissani, Umar. 1985. Dhikrayat La Mudhakkirat (Memories, Not Memoirs). Cairo: Dar al-Tiba‘a wa al-Nashr al-Islamiyya.

Ansari, Hamied. 1986. Egypt, the stalled society. SUNY Press.

Baylouny, Anne Marie. 2010. Privatizing Welfare in the Middle East: Kin Mutual Aid Associations in Jordan and Lebanon. Indiana University Press.

Beinin, Joel. 2012. “The Rise of Egypt's Workers.” Carnegie Papers .

Berman, Sheri. 2003. "Islamism, Revolution, and Civil Society." Perspectives on Politics 1(2):257-272.

Bianchi, Robert. 1986. "The corporatization of the Egyptian labor movement." Middle East Journal 40(3):429-444.

Bin-Nafisa, Sarah and Ala'uddin 'Arafat. 2005. al-Intikhabat wa al-Zaba'iniyya alSiyassiya fi-Misr (Elections and Political Clientelism in Egypt). Cairo Center for Human Rights Studies.

Blaydes, L. 2010. Elections and distributive politics in Mubarak's Egypt. Cambridge Univ Pr.

Blaydes, Lisa. 2006. "Who Votes in Authoritarian Elections and Why? Vote Buying, Turnout, and Spoiled Ballots in Contemporary Egypt." University of California, Los Angeles.

Brown, Nathan J. 1990. Peasant Politics in Modern Egypt: The Struggle Against the State. Yale University Press.

Bush, R. 2011. "Egypt: a permanent revolution?" Review of African Political Economy 38(128):303-307.

Calmfors, Lars and John Driffill. 1988. "Bargaining structure, corporatism and macroeconomic performance." Economic policy pp. 14-61.

Cammett, M. and S. Issar. 2010. "Bricks and Mortar Clientelism: Sectarianism and the Logics of Welfare Allocation in Lebanon." World Politics 62(03):381-421.

Carey, John M. and Matthew Soberg Shugart. 1995. "Incentives to Cultivate a Personal Vote: A Rank Ordering of Electoral Systems." Electoral Studies 14(4):417439. 
Carothers, Thomas and Marina Ottaway. 2004. “Think Again: Middle East Democracy." Foreign Policy .

Clark, J.A. 2004. Islam, charity, and activism: Middle-class networks and social welfare in Egypt, Jordan, and Yemen. Bloomington, IN: Indiana University Press.

Darra, Usama. 2011. Min al-Ikhwan ila Midan al-Tahrir (From the Brotherhood to Tahrir Square). Dar al-Misri lil Nashr.

Derick Brinkerhoff, John S. Holtzman, Adel Mostafa Nabil Habashi. 2002. The impact of the Agricultural Policy Reform Program on the roles of the public and private sectors in Egyptian agriculture. Technical report Government of Egypt, Ministry of Agriculture and Land Reclamation; United States Agency for Interational Development/Egypt Office of Economic Growth, Compeititveness and Agricultural Development Division.

Desai, Manali. 2002. “The Relative Autonomy of Party Practices: A Counterfactual Analysis of Left Party Ascendancy in Kerala, India, 1934-19401." American Journal of Sociology 108(3):616-657.

El-Fattah, Mohamed A. Abd. 2012. A survey-based exploration of statisfaction and profitability in Egypt's informal sector. Working Paper 169 Egyptian Center for Economic Studies.

El-Khawas, M. 2012. “Egypt's Unfinished Revolution." Mediterranean Quarterly 23(1):52-66.

Fahmy, Ninette S. 1998. "The Performance of the Muslim Brotherhood in the Egyptian Syndicates: An Alternative Formula for.." Middle East Journal 52(4):551.

Frank, Thomas. 2004. What's the Matter with Kansas? How Conservatives Won the Heart of America. Metropolitan Books.

Golden, Miriam. 1993. "The dynamics of trade unionism and national economic performance." American Political Science Review pp. 437-454.

Halliday, Fred. 2007. “The Jihadism of fools.” Dissent 54(1):53-56.

Ibrahim, Saad Eddin. 1980. "Anatomy of Egypt's Militant Islamic Groups: Methodological Note and Preliminary Findings." International Journal of Middle East Studies 12(4):423-453.

Jamal, A.A. 2007. Barriers to democracy: The other side of social capital in Palestine and the Arab world. Princeton Univ Pr.

Kandil, Amani. 2004. "Civic service in the Arab region." Nonprofit and voluntary sector quarterly 33(4 suppl):39S-50S.

Kepel, Gilles. 1985. The prophet and pharaoh: Muslim extremism in Egypt. London: Al Saqi Books : Distributed by Zed Books. 
Kienle, Eberhard. 2001. A grand delusion: democracy and economic reform in Egypt. Vol. 32 IB Tauris.

King, Gary. 1997. A Solution to the Ecological Inference Problem: Reconstructing Individual Behavior from Aggregate Data. Princeton University Press.

King, Gary, Michael Tomz and Jason Wittenberg. 2000. "Making the Most of Statistical Analyses: Improving Interpretation and Presentation." American Journal of Political Science 44(2):347-61.

Kitschelt, Herbert. 2000. "Linkages between citizens and politicians in democratic polities." Comparative Political Studies 33(6-7):845-879.

Lesch, Ann M. 1995. Domestic Politics and Foreign Policy in Egypt. In Democracy, war, and peace in the Middle East, ed. Mark Tessler and David Garnham. Vol. Democracy, war, and peace in the Middle East Indiana University Press chapter 10, pp. 223-243.

Lewis, Bernard. 1996. "Islam and Liberal Democracy: A Historical Overview." Journal of Democracy 7(2):52-63.

Lipset, Seymour Martin and Stein Rokkan. 1967. Cleavage Structures, Party Systems, and Voter Alignments: An Introduction. In Party Systems and Voter Alignments: Cross-National Perspectives, ed. Seymour Martin Lipset and Stein Rokkan. Free Press pp. 1-64.

Lughod, Lila Abu. 1995. "Movie Stars and Islamic Moralism in Egypt." Social Text (42):53-67.

Lust-Okar, Ellen. 2006. "Elections under authoritarianism: Preliminary lessons from Jordan." Democratization 13(3):456-71.

Marx, Karl and Friedrich Engels. 2012. The communist manifesto. Yale University Press.

Masoud, Tarek. 2011. "The road to (and from) Liberation Square." Journal of Democracy 22(3):20-34.

Masoud, T.E. 2008. Why Islam Wins: Electoral Ecologies and Economies of Political Islam in Contemporary Egypt PhD thesis Yale University.

Miller, Judith. 1996. God has Ninety-nine Names: Reporting from a Militant Middle East. New York: Simon \& Schuster.

Munson, Ziad. 2001. "Islamic Mobilization: Social Movement Theory and the Egyptian Muslim Brotherhood." Sociological Quarterly 42(4):487-510.

Norris, Pippa and Ronald Inglehart. 2011. Sacred and secular: Religion and politics worldwide. Cambridge University Press. 
Pepinsky, T.B., R.W. Liddle and S. Mujani. 2012. "Testing Islam's Political Advantage: Evidence from Indonesia." American Journal of Political Science .

Posusney, Marsha Pripstein. 1997. Labor and the state in Egypt: workers, unions, and economic restructuring. Columbia University Press.

Rabi`, Amr Hashim. 1997. The 1995 Elections in the Context of Egyptian Political Development. In The 1995 Parliamentary Elections in Egypt, ed. Hala Mustapha. Cairo: Al-Ahram Center for Political and Strategic Studies.

Rubin, Barry. 2007. "Comparing three muslim brotherhoods: Syria, Jordan, Egypt." Middle East Review of International Affairs (Ramat-Gan) 11(2):107-116.

Rutherford, B.K. 2008. Egypt after Mubarak: liberalism, Islam, and democracy in the Arab world. Princeton Univ Pr.

Said, Edward. 1978. Orientalism: Western Conceptions of the Orient. New York: Pantheon.

Shehata, S. 2008. Inside an Egyptian parliamentary campaign. In Political Participation in the Middle East, ed. Lust-Okar and Zerhouni. Lynne Reinner pp. 95-120.

Snee, Ronald D and Donald W Marquardt. 1984. "Comment." The American Statistician 38(2):83-87.

Sullivan, Denis J. 1994. Private Voluntary Organizations in Egypt: Islamic Development, Private Initiative, and State Control. University Press of Florida.

Tadros, M. 2005. “Egypt's Election All About Image, Almost." Middle East Report Online, September 6.

Tessler, Mark and Jodi Nachtwey. 1998. "Islam and Attitudes toward International Conflict: Evidence from Survey Research in the Arab World." Journal of Conflict Resolution 42(5):619-636.

Tingay, Caroline Laetitia. 2006. Agrarian Transformation in Egypt: Conflict Dynamics and the Politics of Power from a Micro Perspective PhD thesis Free University of Berlin.

Trager, E. 2011. "Unbreakable Muslim Brotherhood: Grim Prospects for a Liberal Egypt, The." Foreign Aff. 90:114.

Trager, Eric. 2013. "Egypt's Looming Competitive Theocracy." Current Trends in Islamist Ideology 14:27-38.

Tsai, Lily L. 2007. "Solidary groups, informal accountability, and local public goods provision in rural China." American Political Science Review 101(2):355.

Watts, Susan. 1993. Local Level Political and Social Structure: The Literature in English. United States Agency for International Development. 
Weber, Max. 1946. Science as a Vocation. In From Max Weber: Essays in Sociology, ed. H.H. Gerth and C. Wright Mills. Oxford University Press pp. 129-156.

Wedeen, Lisa. 2002. "Conceptualizing Culture: Possibilities for Political Science." American Political Science Review 96(4):713.

Wiktorowicz, Quintan. 2001. The management of Islamic activism : Salafis, the Muslim Brotherhood, and state power in Jordan. Albany, NY: State University of New York Press.

Wiktorowicz, Quintan, ed. 2004. Islamic Activism: A Social Movement Theory Approach. Indiana University Press.

Zaki, Moheb. 1995. Civil Society and Democratization in Egypt: 1981-1994. Konrad Adenauer Stiftung. 